\title{
Quantification of surface water volume changes in the Mackenzie Delta using satellite multi-mission data
}

\author{
Cassandra Normandin ${ }^{1}$, Frédéric Frappart ${ }^{2,3}$, Bertrand Lubac ${ }^{1}$, Simon Bélanger $^{4}$, Vincent Marieu ${ }^{1}$, Fabien Blarel ${ }^{3}$, \\ Arthur Robinet $^{1}$, and Léa Guiastrennec-Faugas ${ }^{1}$ \\ ${ }^{1}$ EPOC, UMR 5805, Université de Bordeaux, Allée Geoffroy Saint-Hilaire, 33615 Pessac, France \\ ${ }^{2}$ GET-GRGS, UMR 5563, CNRS/IRD/UPS, Observatoire Midi-Pyrénées, 31400 Toulouse, France \\ ${ }^{3}$ LEGOS-GRGS, UMR 5566, CNRS/IRD/UPS, Observatoire Midi-Pyrénées, 31400 Toulouse, France \\ ${ }^{4}$ Dép. Biologie, Chimie et Géographie, groupe BOREAS and Québec-Océan, Université du \\ Québec à Rimouski, 300 allée des ursulines, Rimouski, Qc, G5L 3A1, Canada
}

Correspondence: Cassandra Normandin (cassandra.normandin@u-bordeaux.fr)

Received: 22 March 2017 - Discussion started: 29 May 2017

Revised: 5 December 2017 - Accepted: 11 January 2018 - Published: 28 February 2018

\begin{abstract}
Quantification of surface water storage in extensive floodplains and their dynamics are crucial for a better understanding of global hydrological and biogeochemical cycles. In this study, we present estimates of both surface water extent and storage combining multi-mission remotely sensed observations and their temporal evolution over more than 15 years in the Mackenzie Delta. The Mackenzie Delta is located in the northwest of Canada and is the second largest delta in the Arctic Ocean. The delta is frozen from October to May and the recurrent ice break-up provokes an increase in the river's flows. Thus, this phenomenon causes intensive floods along the delta every year, with dramatic environmental impacts. In this study, the dynamics of surface water extent and volume are analysed from 2000 to 2015 by combining multi-satellite information from MODIS multispectral images at $500 \mathrm{~m}$ spatial resolution and river stages derived from ERS-2 (1995-2003), ENVISAT (2002-2010) and SARAL (since 2013) altimetry data. The surface water extent (permanent water and flooded area) peaked in June with an area of $9600 \mathrm{~km}^{2}\left( \pm 200 \mathrm{~km}^{2}\right)$ on average, representing approximately $70 \%$ of the delta's total surface. Altimetrybased water levels exhibit annual amplitudes ranging from $4 \mathrm{~m}$ in the downstream part to more than $10 \mathrm{~m}$ in the upstream part of the Mackenzie Delta. A high overall correlation between the satellite-derived and in situ water heights $(R>0.84)$ is found for the three altimetry missions. Finally, using altimetry-based water levels and MODIS-derived surface water extents, maps of interpolated water heights over
\end{abstract}

the surface water extents are produced. Results indicate a high variability of the water height magnitude that can reach $10 \mathrm{~m}$ compared to the lowest water height in the upstream part of the delta during the flood peak in June. Furthermore, the total surface water volume is estimated and shows an annual variation of approximately $8.5 \mathrm{~km}^{3}$ during the whole study period, with a maximum of $14.4 \mathrm{~km}^{3}$ observed in 2006 . The good agreement between the total surface water volume retrievals and in situ river discharges $(R=0.66)$ allows for validation of this innovative multi-mission approach and highlights the high potential to study the surface water extent dynamics.

\section{Introduction}

Deltas are vulnerable to both anthropogenic and natural forcing such as socio-economic infrastructure development and global warming. In the Arctic, the latter is particularly severe due to the polar amplification processes and complex positive feedback loops (Holmes et al., 2012). This system is undergoing important changes, as the increase in precipitation at high latitudes increases river discharge and melting of stock ices on land and sea (Stocker and Raible, 2005). These changes may induce an acceleration of the hydrologic cycle (Stocker and Raible, 2005). River discharge may increase from 18 to $70 \%$ from now to the end of the century (Peterson et al., 2002). Improving our knowledge on the dynamics of 
the surface water reservoir in circumpolar areas is crucial for a better understanding of their role in flood hazard, carbon production, greenhouse gases emission, sediment transport, exchange of nutrients and land-atmosphere interactions.

Mapping surface water extent on the scale of the Mackenzie Delta is an important issue. However, it is nearly impossible to provide long-term monitoring with traditional methods using in situ measurements in such a large and heterogeneous environment. Satellite remote sensing method offers a unique opportunity for the continuous observation of wetlands and floodplains. Remote sensing has been proven to have strong potential to detect and monitor floods during the last 2 decades (Alsdorf et al., 2007; Smith, 1997). Typically, two kinds of sensor are used to map flooded areas at high and moderate resolutions: passive multispectral imagery and active synthetic aperture radar (SAR). The spectral signature of the surface reflectance is used to discriminate between water and land (Rees, 2013). The SAR images provide valuable information on the nature of the observed surface through the backscattering coefficient (Ulaby et al., 1981).

If space missions of radar altimetry were mainly dedicated to estimate ocean surface topography ( $\mathrm{Fu}$ and Cazenave, 2001), it is now commonly used for monitoring inland water levels (Birkett, 1995; Cazenave et al., 1997; Frappart et al., 2006a, 2015b; Santos da Silva et al., 2010; Crétaux et al., 2011a, 2017). Several studies have shown the possibility to measure water levels variations in lakes, rivers and flooding plains (Frappart et al., 2006b, 2015a; Santos da Silva et al., 2010). In the present study, satellite multispectral imagery and altimetry are used in synergy to quantify surface water extents and the surface water volumes of the Mackenzie Delta and analyse their temporal variations. In the past, this approach has been applied in tropical (e.g. the Amazon, Frappart et al., 2012; Mekong, Frappart et al., 2006b) and peri-Arctic (e.g. the Lower Ob' basin, Frappart et al., 2010) major river basins, allowing direct observations of the spatiotemporal dynamics of surface water storage. Several limitations prevent their use over estuaries and deltas. The first is the too-coarse spatial resolution of the datasets used for retrieving the flood extent that ranges from $1 \mathrm{~km}$ with SPOTVGT images used in the lower Mekong Basin to $\sim 0.25^{\circ}$ with the Global Inundation Extent from Multi-Satellite (GIEMS, Papa et al., 2010) dataset for the Lower Ob' and the Amazon basins. The second is inherent to the datasets used in these studies. For the Mekong Basin, due to the limited number of spectral bands present in the VGT sensor, a mere threshold on the normalized difference vegetation index (NDVI) was applied. For the Amazon and the Lower Ob', as the GIEMS dataset is using surface temperatures from the Special Sensor Microwave Imager (SSM/I), no valid data are available at less than $50 \mathrm{~km}$ from the coast. The originality and novelty of the study stem from the use of multi-space mission data at better spatial, temporal and spectral resolutions than the previous studies to monitor surface water storage changes in a deltaic environment over a 15 -year time period.
Earlier studies pointed out (i) the lack of continuous information in the Mackenzie delta to study the spatial distribution of water levels during the flood events and to analyse the relationship between flood severity and the timing and duration of break-up in the delta (Goulding et al., 2009b; Beltaos et al., 2012) and (ii) the importance of the tributaries to the Mackenzie River (i.e. Peel and Arctic Red rivers) on break-up and ice-jam flooding in the delta (Goulding et al., 2009a). As the goal of this study is to characterize the spatiotemporal surface and storage dynamics of surface water in the Mackenzie delta, Northwest Territories of Canada, in response to spring ice break-up and snow melt, over the period 2000-2015, it will provide important new information for a better understanding of the hydro-climatology of the region.

\section{Study region}

The Mackenzie Delta, a floodplain system, is located in the northern part of Canada (Fig. 1a) and covers an area of $13135 \mathrm{~km}^{2}$ (Emmerton et al., 2008), making it the second biggest delta of Arctic with a length of $200 \mathrm{~km}$ and a width of $80 \mathrm{~km}$ (Emmerton et al., 2008). It is mainly drained by the Mackenzie River ( $90 \%$ of the delta's water supply) and Peel River ( $8 \%$ of the delta's water supply, Emmerton et al., 2007). The Mackenzie Delta channels have very mild slopes $\left(-0.02 \mathrm{~m} \mathrm{~km}^{-1}\right.$; Hill et al., 2001), and are ice-covered during 7-8 months per year (Emmerton et al., 2007).

The Mackenzie River begins in the Great Slave Lake and then, flows through the Northwest Territories before reaching the Beaufort Sea. It has a strong seasonality in term of discharge due to spring ice break-up and snowmelt, from about $5000 \mathrm{~m}^{3} \mathrm{~s}^{-1}$ in winter up to $40000 \mathrm{~m}^{3} \mathrm{~s}^{-1}$ in June during the ice break-up for wet years (Fig. 1b, Macdonald and Yu, 2006; Goulding et al., 2009a, b; Beltaos et al., 2012). The Stamukhi (ground accumulation of sea ice) is responsible for recurrent floods in the Mackenzie Delta. At the flood peak, $95 \%$ of the delta surface is likely to be covered with water (Macdonald and $\mathrm{Yu}, 2006$ ). Water level peaks are mainly controlled by ice break-up effects and secondarily by the amount of water contained in snowpack (Lesack and Marsh, 2010). This is one of the most important annual hydrologic events in cold regions (Muhammad et al., 2016).

The delta is a complex of multiple channels and numerous shallow and small lakes (over 49000 lakes), covering nearly $\sim 50 \%$ of the delta area (Emmerton et al., 2007), which are ecologically sensitive environments largely controlled by river water (Squires et al., 2009). This environment is also one of the most productive ecosystems in northern Canada, with large populations of birds, fish and mammals, which are critical resources for local population (Squires et al., 2009). 


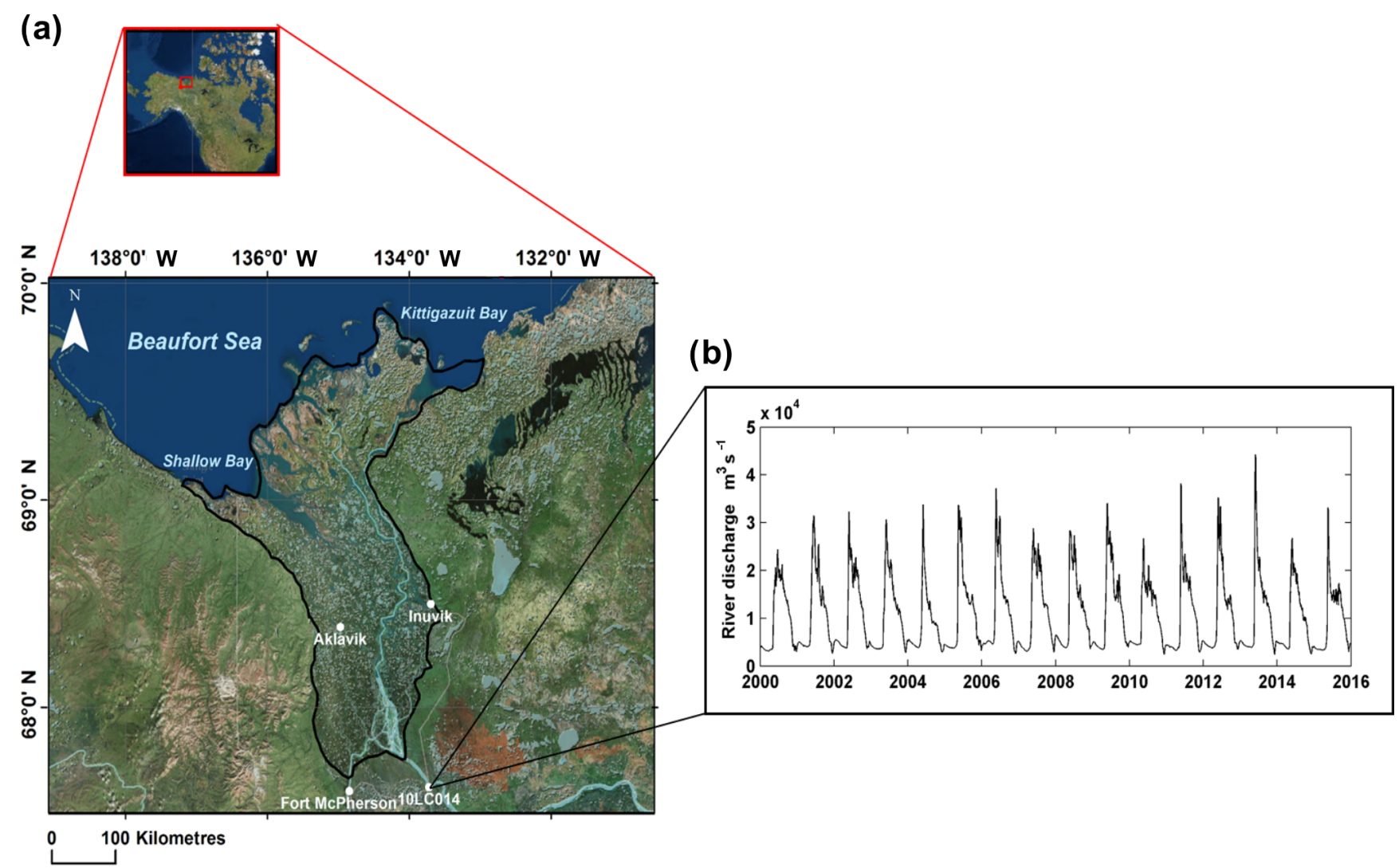

Figure 1. (a) Location of the Mackenzie Delta at the mouth of the Mackenzie River in the Northwest Territories of Canada. (b) River discharges of the Mackenzie River at 10LC014 station from 2000 to $2015\left(133^{\circ} \mathrm{W}, 67^{\circ} \mathrm{N}\right), 30 \mathrm{~km}$ upstream the Mackenzie Delta.

\section{Datasets}

\subsection{Multispectral imagery}

\subsubsection{MODIS}

The Moderate Resolution Imaging Sensor (MODIS) is a spectroradiometer, part of the payload of the Aqua (since 2002) and Terra (since 1999) satellites. The MODIS sensor measures radiances in 36 spectral bands. In this study, the MOD09A1 product (8-day binned level 3, version 6) derived from Terra satellite surface reflectance measurements were downloaded from the United States Geological Survey (USGS) EarthExplorer website (https://ladsweb.modaps. eosdis.nasa.gov/). It consists of gridded, atmospherically corrected surface reflectance acquired in seven bands from visible to shortwave infrared (SWIR) $(2155 \mathrm{~nm})$ at a $500 \mathrm{~m}$ spatial resolution. This product is obtained by combining for each wavelength the best surface reflectance data of every pixel acquired during an 8-day period. Each MODIS tile covers an area of $1200 \mathrm{~km}$ by $1200 \mathrm{~km}$. Two tiles (h12v02 and h13v02) are used to cover the whole study area. In this study, 223 composites, acquired during the ice-free period from June to September over the 2000-2015 time span, are used.

\subsubsection{OLI}

The Landsat- 8 satellite is composed of two Earth-observing sensors, the Operational Land Imager (OLI) and Thermal InfraRed Sensor (TIRS). This satellite was launched in February 2013 and orbits at an altitude of $705 \mathrm{~km}$. The swath is $185 \mathrm{~km}$ and the whole Earth surface is covered every 16 days.

The OLI-TIRS sensors measure in 11 spectral bands in the visible $(450-680 \mathrm{~nm})$, near-infrared $(845-885 \mathrm{~nm})$ and shortwave infrared $(1560-2300 \mathrm{~nm})$ portions of the electromagnetic spectrum. In this study, the Landsat- 8 OLI surface reflectance products were downloaded from the Landsat- 8 USGS portal (http://earthexplorer.usgs.gov/). The multispectral spatial resolutions are 30 and $15 \mathrm{~m}$ for panchromatic bands. Two images are necessary to cover the Mackenzie Delta.

Landsat- 8 mission is characterized by a lower revisit time than the Terra and Aqua missions. Thus, associated with a high occurrence of clouds over the study area, Landsat- 8 yields a small amount of high-quality data. Consequently, OLI images cannot be used in this study to monitor water surface area temporal changes. In this context, MODIS represents a relevant alternative to OLI despite a lower spatial res- 
olution. However, available high-quality OLI data have been used to compare and validate MODIS water surface areas.

\subsection{Radar altimetry data}

\subsubsection{ERS-2}

The ERS-2 satellite (European Remote Sensing) was launched in 1995 by the European Space Agency (ESA). Its payload is composed of several sensors, including a radar altimeter (RA), operating at the $\mathrm{K}_{\mathrm{u}}$ band $(13.8 \mathrm{GHz})$. It was orbiting sun-synchronously at an altitude of $790 \mathrm{~km}$ with an inclination of $98.54^{\circ}$ with a 35-day repeat cycle. This orbit was ERS-1's orbit with a ground-track spacing about $85 \mathrm{~km}$ at the Equator. ERS-2 provides observations of the topography of the Earth from $82.4^{\circ}$ latitude north to $82.4^{\circ}$ latitude south. ERS-2 data are disposable from 17 May 1995 to 9 August 2010 but after 22 June 2003, the coverage is limited.

\subsubsection{ENVISAT}

Envisat mission was launched on 1 March 2002 by ESA. This satellite carried 10 different instruments including the advanced radar altimeter (RA-2). It was based on the heritage of ERS-1 and 2 satellites. RA-2 was a nadir-looking pulse-limited radar altimeter operating at two frequencies at $\mathrm{K}_{\mathrm{u}}(13.575 \mathrm{GHz})$ and $\mathrm{S}(3.2 \mathrm{GHz})$ bands. Its goal was to collect radar altimetry over ocean, land and ice caps (Zelli, 1999). Envisat remained on its nominal orbit until October 2010 but RA-2 stopped operating correctly at the $\mathrm{S}$ band in January 2008. Its initial orbital characteristics are the same as for ERS-2.

\subsubsection{SARAL}

SARAL mission was launched on 25 February 2013 by a partnership between CNES (Centre National d'Etudes Spatiales) and ISRO (Indian Space Research Organization). Its payload comprised the AltiKa radar altimeter and bifrequency radiometer, and a triple system for precise orbit determination: the real-time tracking system DIODE of the DORIS instrument, a laser retroflector array (LRA), and the Advance Research and Global Observation Satellite (ARGOS-3). AltiKa is the first radar altimeter to operate at the $\mathrm{K}_{\mathrm{a}}$ band $(35.75 \mathrm{GHz})$. It is a solid-state mono-frequency altimeter that provides precise range estimates (Verron et al., 2015). SARAL orbit was earlier utilized by ERS-1 \& 2 and ENVSAT missions with a track spacing of $85 \mathrm{~km}$ at the Equator (Verron et al., 2015). It has been put on a drifting orbit since 4 July 2016.

Altimetry data used here are contained in the Interim Geophysical Data Records (GDRs) and are the following:

- cycle 001 (17 May 1995) to cycle 085 (7 August 2003) for ERS-2 from the reprocessing of the ERS-2 mission raw waveform performed at Centre de Topographie de
l'Océan et de l'Hydrosphère (CTOH) (Frappart et al., 2016)

- GDR v2.1 for ENVISAT from cycle 006 (14 May 2002) to cycle 094 (21 October 2010)

- GDR E for SARAL from cycle 001 (15 March 2015) to cycle 027 (14 October 2015).

These data were made available by CTOH (http://ctoh.legos. obs-mip.fr/). Data were acquired along the altimeter track at 18, 20 and $40 \mathrm{~Hz}$ for ENVISAT, ERS - 2 and SARAL respectively (high-frequency mode commonly used over land and coastal areas where the surface properties are changing more rapidly than over the open ocean). They consist of the satellite locations and acquisition times and all the parameters necessary to compute the altimeter heights (see Sect. 4.3).

\subsection{In situ water levels and discharges}

The altimetry-based water level time series derived from radar altimetry were compared to gauge records from in situ stations for validation purpose. Data from 10 gauge stations were found in close vicinity to altimetry virtual stations (VSs; at a distance of less than $20 \mathrm{~km}$ along the streams). Virtual stations are built at intersections between an orbit ground rack and a water body (lake, river and floodplain) (Crétaux et al., 2017). Besides, surface water storage variations were compared to the river flow entering the delta, summing the records from three gauge stations located in upstream part of the delta. Daily data of water level and discharge were downloaded for free from the Canadian government website (http://wateroffice.ec.gc.ca).

\section{Methods}

\subsection{Quantification of surface water extent}

Multispectral imagery is commonly used for delineating flood extent using spectral indices (e.g. Frappart et al., 2006b; Sakamoto et al., 2007; Crétaux et al., 2011b; Verpoorter et al., 2014; Ogilvie et al., 2015; Pekel et al., 2016). As we do not have any external information to perform a supervised classification using the current state-of-theart machine learning techniques (Pekel et al., 2016; Tulbure et al., 2016; Klein et al., 2017), we used the approach proposed by Sakamoto et al. (2007) to monitor the water surface area extent in the Mackenzie Delta (Fig. 2). This approach is based on the application of thresholds on the enhanced vegetation index (EVI), the land surface water index (LSWI) and the difference value between EVI and LSWI (DVEL $=$ EVI - LSWI) to determine the status (non-flooded, mixed, flooded and permanent water body) of any pixel in an 8-day MODIS composite image of surface reflectance. As the spectral response of the near infrared (NIR) and shortwave infrared bands is highly depen- 
dent on the Earth surface nature, in particular water versus soil-vegetation surfaces, their complement was used to define LSWI. For instance, the surface reflectance presents low values (a few percentage points) over non-turbid water bodies and high values (a few tens of percentage points) over vegetation feature in the NIR spectral bands. The spectral response in the SWIR is mainly dominated by strong water absorption bands, which is directly sensitive to moisture content in the soil and the vegetation. For water surface area, the signal in the SWIR is assumed to be zero even in turbid waters (Wang and Shi, 2005). Thus, LSWI is expected to get values close to 1 for water surface areas and lower values for non-water surface areas.

The two indices, used in this approach, are defined as follows (Huete et al., 1997; Xiao et al., 2005):

$$
\begin{aligned}
& \mathrm{EVI}=a \times \frac{\rho_{\mathrm{NIR}}-\rho_{\text {red }}}{\rho_{\mathrm{NIR}}+b \times \rho_{\text {red }}-c \times \rho_{\text {blue }}+d}, \\
& \mathrm{LSWI}=\frac{\rho_{\mathrm{NIR}}-\rho_{\mathrm{SWIR}}}{\rho_{\mathrm{NIR}}+\rho_{\mathrm{SWIR}}},
\end{aligned}
$$

where for MODIS, $\rho_{\text {blue }}$ is the surface reflectance value in the blue (459-479 $\mathrm{nm}$, band 3), $\rho_{\text {red }}$ is the surface reflectance value in the red $(621-670 \mathrm{~nm}$, band 1$), \rho_{\mathrm{NIR}}$ is the surface reflectance value in the NIR $(841-875 \mathrm{~nm}$, band 2$)$, and $\rho_{\text {SWIR }}$ is the surface reflectance in the SWIR $(1628-1652 \mathrm{~nm}$, band 6$)$. For OLI, $\rho_{\text {blue }}, \rho_{\text {red }}, \rho_{\text {NIR }}$, and $\rho_{\text {SWIR }}$ are associated with channel $2(452-512 \mathrm{~nm})$, channel $4(636-673 \mathrm{~nm})$, channel 5 (851-879 nm), and channel 6 (1570-1650 nm), respectively. The constants $a, b, c$ and $d$ are equal to $2.5,6,7.5$ and 1, respectively, for both MODIS and OLI (USGS, product guide).

To process multispectral images, the first step consists of removing the cloud-contaminated pixels by applying a cloud masking based on a threshold of the surface reflectance in the blue band ( $\rho_{\text {blue }} \geq 0.2$ ). Then, spectral indices are computed. Note that, contrary to Sakamoto et al. (2007), no smoothing was applied on spectral index time series. In a second step, the identification of the status of each pixel is performed by applying thresholds on EVI, LSWI and their differences (Fig. 2), which reduce the noise component. Thresholds determined by Sakamoto et al. (2007) were validated for our study site using OLI images acquired on 1 July and 2 August 2013 and compared to MODIS (Fig. S1 in the Supplement). Histograms show a similar bi-modal distribution for both EVI, LSWI and EVI-LSWI between MODIS and OLI $500 \mathrm{~m}$ (Figs. S1 and S2). For EVI, pixels with a value lower than 0.1 are clearly associated with water land surfaces, while pixels with a value higher than 0.3 are associated with soil and vegetation features. Other pixels, with an EVI value between 0.1 and 0.3 , are identified as mixed surface types. For LSWI, pixels with a value higher than 0.5 are clearly associated with water land surfaces, while pixels with a value lower than 0.3 are associated with vegetation features or soil land surfaces when LSWI values are negative. Other pixels, with an LSWI value between 0.3 and 0.5 , are identified as mixed

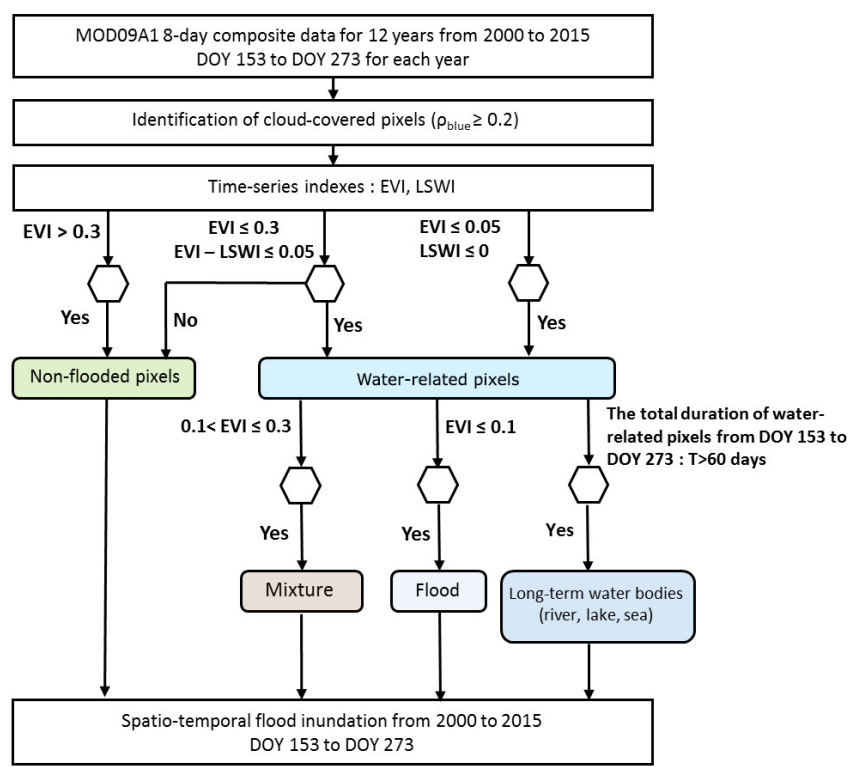

Figure 2. Flow chart of the method (adapted from Sakamoto et al., 2007) used to classify each pixel of the multispectral images acquired over the Mackenzie Delta in four categories (non-flooded, mixed, flooded and permanent water bodies) for each year from 2000 to 2015 using MODIS 8-day composite data from the day of the year (DOY) 169 to 257.

surface types. Contrary to what was found by Sakamoto et al. (2007) in the Mekong Basin, no negative values of LSWI were observed over our study area. This threshold was not applied in this study. For EVI-LSWI, pixels with a value lower than -0.05 represent water land surface and values between -0.05 and 0.1 are associated with mixed pixels. Other pixels, with values higher than 0.1 are represented vegetation features or soil land surfaces (Fig. S2). Each pixel was then classified in two main categories: non-flooded (EVI $>0.3$ or $\mathrm{EVI} \leq 0.3$ but $\mathrm{EVI}-\mathrm{LSWI}>0.05)$ and water-influenced $(\mathrm{EVI} \leq 0.3$ and $\mathrm{EVI}-\mathrm{LSWI} \leq 0.05$ or $\mathrm{EVI} \leq 0.05)$ (Fig. 2). The second category was divided into three sub-classes: mixed pixels $(0.1<\mathrm{EVI} \leq 0.3)$, flooded pixels $(\mathrm{EVI} \leq 0.1)$ and permanent water bodies (e.g. lake, river and sea), the latter denoting when the total duration of a pixel classified as flooded is longer than 70 days out of 105 days for the study period. This annual duration for our study corresponds roughly to two-thirds of the study period, as proposed by Sakamoto et al. (2007). The spatio-temporal variations of floods have been characterized for the months between June and September over the 2000-2015 period.

Hereafter, in this paper we define water surface area as permanent water bodies with flooded areas, although inundated surfaces include only inundated areas. 


\subsection{Validation of MODIS retrievals using OLI}

Evaluation of the performance of the water surface area detection from MODIS is based on the comparison between land surface water estimated from MODIS at a $500 \mathrm{~m}$ resolution, OLI at a $30 \mathrm{~m}$ resolution, and OLI re-sampled at $500 \mathrm{~m}$ resolution. For validation purposes, MODIS and OLI images are selected when (1) the time difference between the acquisitions of two satellite images is lower than 3 days and (2) the presence of cloud over the area is lower than $5 \%$. Following these criteria, only two cloud-free OLI composites were selected between 1 July and 2 August 2013.

\subsection{Satellite-derived water level time series in the Mackenzie Delta}

The concept of radar altimetry is explained below. The radar emits an electromagnetic (EM) wave towards the surface and measures the round-trip time $(\Delta t)$ of the EM wave. Taking into account propagation corrections caused by delays due to the interactions of electromagnetic waves in the atmosphere, and geophysical corrections, the height of the reflecting surface $(h)$ with reference to an ellipsoid can be estimated as follows (Crétaux et al., 2017):

$h=H-\left(R+\sum \Delta R_{\text {propagation }}+\Delta R_{\text {geophysical }}\right)$,

where $H$ is the satellite centre of mass height above the ellipsoid, $R$ is the nadir altimeter range from the satellite centre of mass to the surface (taking into account instrument corrections; $R=c \Delta t / 2$, where $c$ is the light velocity in the vacuum), and $\sum \Delta R_{\text {propagation }}$ is the sum of the geophysical and environmental corrections applied to the range.

$\sum \Delta R_{\text {propagation }}=\Delta R_{\text {ion }}+\Delta R_{\text {dry }}+\Delta R_{\text {wet }}$,

where $\Delta R_{\text {ion }}$ is the atmospheric refraction range delay due to the free electron content associated with the dielectric properties of the ionosphere, $\Delta R_{\text {dry }}$ is the atmospheric refraction range delay due to the dry gas component of the troposphere, and $\Delta R_{\text {wet }}$ is the atmospheric refraction range delay due to the water vapour and the cloud liquid water content of the troposphere.

$\sum \Delta R_{\text {geophysical }}=\Delta R_{\text {solid Earth }}+\Delta R_{\text {pole }}$,

where $\Delta R_{\text {solid Earth }}$ and $\Delta R$ pole are the corrections respectively accounting for crustal vertical motions due to the solid Earth and pole tides. The propagation corrections applied to the range are derived from model outputs: the global ionospheric maps (GIMs) and Era-Interim datasets from the European Centre for Medium-Range Weather Forecasts (ECMWF) for the ionosphere and the dry and wet troposphere range delays respectively. The changes in the altimeter height $h$ over the hydrological cycles are related to variations in water level. Here, the Multi-mission Altimetry Processing Software (MAPS) was used to precisely select valid altimetry data at every virtual station location (see Sect. 3.3) series in the Mackenzie Delta. Data processing consisted of four steps (Frappart et al., 2015b):

- the rough delineation of the river-lake cross sections with overlaying altimeter tracks using Google Earth (distances of $\pm 5 \mathrm{~km}$ from the river banks are generally considered);

- the loading of the altimetry over the study area and the computation of the altimeter heights from the raw data contained in the GDRs;

- the selection of valid altimetry data through a refined process that consists of eliminating outliers and measurements over non-water surface areas based on visual inspection (the shape of the altimeter along-track profiles permit identification of the river that is generally materialized as a shape of " $V$ " or " $U$ ", with the lower elevations corresponding to the water surface area; see Santos da Silva et al., 2010 and Baup et al., 2014 for more details);

- the computation of the time series of water level.

\subsection{Surface water volume storage}

The approach used to estimate the anomalies of surface water volume is based on the combination of the surface water extent derived from MODIS images with altimetry-based water levels estimated at virtual stations distributed all over the delta (Fig. 5). Surface water level maps were computed from the interpolation of water levels over the water surface areas using an inverse-distance weighting spatial interpolation technique following Frappart et al. (2012). Hence, water level maps were produced every 8 days from 2000 to 2015 . For each water pixel, the minimal height of water during 2000-2015 is estimated. As ERS-2, ENVISAT and SARAL had a repeat cycle of 35 days, water levels are linearly interpolated every 8 days to be combined with the MODIS composite images.

Surface water volume time series are estimated over the Mackenzie Delta following Frappart et al. (2012):

$V=\sum_{j \in S}\left[h\left(\lambda_{j}, \varphi_{j}\right)-h_{\min }\left(\lambda_{j}, \varphi_{j}\right)\right] \cdot \delta_{j} \cdot \Delta S$,

where $V$ is the anomaly of surface water volume $\left(\mathrm{km}^{3}\right), \mathrm{S}$ is the surface of the Mackenzie Delta $\left(\mathrm{km}^{2}\right), h(\lambda \mathrm{j}, \varphi \mathrm{j})$ the water level, $h_{\min }\left(\lambda_{j}, \varphi_{j}\right)$ the minimal water level for the pixel of coordinates $\left(\lambda_{j}, \varphi_{j}\right)$ inside the Mackenzie Delta, $\delta_{j}$ equals 1 if the $j$ th pixel is associated with permanent water body/inundated and 0 if not and $\Delta S$ the pixel surface $\left(0.25 \mathrm{~km}^{2}\right)$. 

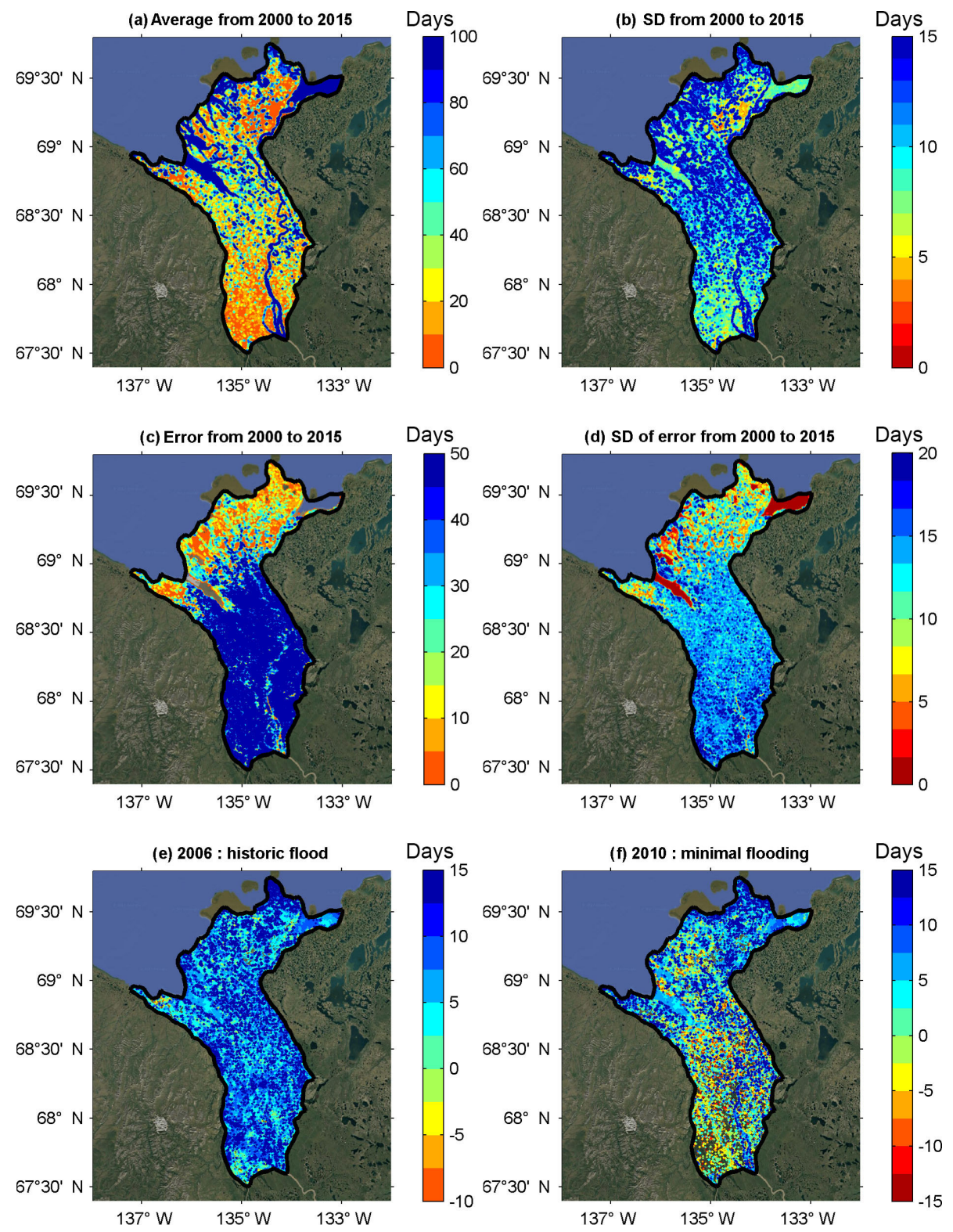

Figure 3. Maps of surface water extent duration for (a) annual average from 2000 to 2015, (b) annual standard deviation from 2000 to 2015, (c) error average from 2000 to 2015, (d) standard deviation from 2000 to 2015, difference between annual average water surface area duration from 2000 to 2015 and water surface area duration during (e) 2006, the period associated with the highest flood event, and (f) 2010, the period associated with the lowest flood event recorded over the period.

\section{Results}

\subsection{MODIS-based land water extent and their validation}

Following the method of Sakamoto et al. (2007), all pixels of 8-day image have been classified into four groups: class 0 corresponding to vegetation, class 1 to permanent water, class 2 to inundation, and class 3 to a mixture of land and water. A map of annual average of water surface area, composed of inundated and permanent water bodies (classes 1 and 2), was obtained at spatial and temporal resolutions of $500 \mathrm{~m}$ and 8 days respectively from June to September over the 2000-2015 period (Fig. 3a). A map of annual average of water surface area duration along with associated standard deviation over 2000-2015 during an ice-free period of 3.5 months (105 days) is presented in Fig. 3b. Permanent water bodies (i.e. identified as water surface area more than 70 days annually) are located along the Mackenzie River main channel, its tributaries (Reindeer, Peel, Middle and East channels) and major lakes of the Delta. The longer water areas (i.e. identified as flooded between 30 and 70 days annually) are 
surrounding permanent water bodies. Other areas of the delta are annually inundated up to 30 days (Fig. 3a). The map of standard deviation of the annual flood duration shows ranges from a few days over the areas affected by floods during a short time span to 15 days close to permanent water bodies (Fig. 3b).

Maps of errors made on water surface area duration with associated standard deviation are shown in Fig. $3 \mathrm{c}$ and d over 2000-2015. Mixed pixels have been used to calculate the error for each pixel on water surface area duration, corresponding to the class 3 "mixed" of Sakamoto et al. (2007) classification. Standard deviation is presented in Fig. 3d. Maximal error and standard deviation is obtained for pixels of potential flooding area in the delta. If short differences - lower than $20 \pm 12$ days - can be observed in the downstream part of the delta (over $69^{\circ} \mathrm{N}$ ), longer differences ( 30 to $50 \pm 15$ to 20 days) are present in the upstream part. They can be attributed to the presence of small permanent lakes in this area. Important inter-annual differences can be observed between wetter (Fig. 3e) and dryer (Fig. 3f) years.

Surface water extent (the sum of permanent bodies and inundated areas) were also estimated by applying the approach described in Sect. 3.1 for OLI images at $30 \mathrm{~m}$ of spatial resolution, and resampled at $500 \mathrm{~m}$ of spatial resolution. They were compared to MODIS-based surface water extent for the closest date (Table 1). Figure S3a, b and c present the maps of the surface water extent determined using MODIS, OLI $500 \mathrm{~m}$ and OLI $30 \mathrm{~m}$ respectively, acquired in July 2013. Medium and large-scale (with a minimal size of $300 \mathrm{~m}$ ) land water features are well detected, as displayed in the enlarged part of the images. Figure S3c presents an enlarged image of surface water extent using OLI $30 \mathrm{~m}$ with permanent and inundated bodies. Surface water extent from OLI $500 \mathrm{~m}$ and MODIS are similar for both dates, with differences lower than $20 \%$ (Table 1). For example in July 2013, water surface area is about $4499 \mathrm{~km}^{2}$ for OLI 500 and $3798 \mathrm{~km}^{2}$ for MODIS (Table 1). Percentages of common detection of surface water were estimated for the pixels detected as water surface area in the pair of satellite images. These percentages are 73 and $74 \%$ for July and August 2013, respectively. Areas detected as water by both sensors correspond to the main channels and connected floodplains. Differences appear on the boundaries of areas commonly detected as inundated and on small scales and can be attributed to the difference of acquisition dates between MODIS and OLI (Fig. S4). These results highlight the robustness of the method of Sakamoto et al. (2007) for accurate water surface area retrievals. These surface water extents have been compared with surface water extents (channels and wetlands) determined by Emmerton et al. (2007) in Table 1. For MODIS, differences are lower than $15 \%$ and for OLI 500 differences are about $25 \%$ (Table 1).

However, the comparison between surface water extent estimated from OLI $30 \mathrm{~m}$ and MODIS $500 \mathrm{~m}$ shows important differences. In July 2013, surface water extent is about $3798 \mathrm{~km}^{2}$ from MODIS and $7685 \mathrm{~km}^{2}$ from OLI 30. The sur- face extents are higher for OLI 30 by a factor of 2 (Table 1 ). According to Emmerton et al. (2007), the Mackenzie Delta is composed of 49000 lakes with a mean area of $0.0068 \mathrm{~km}^{2}$ and $40 \%$ of the total number of lakes have an area inferior to $0.25 \mathrm{~km}^{2}$. The pixel sizes of OLI $30 \mathrm{~m}$ and MODIS $500 \mathrm{~m}$ are approximately 0.0009 and $0.25 \mathrm{~km}^{2}$, respectively. Thus, the high difference between the water surface areas detected using OLI $30 \mathrm{~m}$ and MODIS is probably associated with a spatial sample bias. Small-scale water features detected from OLI cannot be detected from MODIS due to a lower spatial resolution.

Surface water extents determined using OLI 30 have been compared to Emmerton et al. (2007) surface water extents (including channels, wetlands and lakes). Emmerton et al. (2007) classified the Mackenzie Delta habitat in lakes, channels, wetlands and dry floodplains using information from topographic maps derived from aerial photographs taken during the 1950s for low-water periods. Differences between surface water extent of OLI 30 and Emmerton et al. (2007) are lower than $15 \%$ (Table 1).

In order to investigate the assumption of spatial sample bias associated with MODIS $500 \mathrm{~m}$, a satellite validation of surface water extent is performed (Table 2). Permanent water and inundated surfaces have been calculated for MODIS, OLI 500 and OLI 30. For OLI 30 and OLI 500, pixels identified as surface water for the two dates are considered as permanent waters (Table 2). In July 2013, inundated surfaces are nearly equal, about $577 \mathrm{~km}^{2}$ for MODIS, $690 \mathrm{~km}^{2}$ for OLI 500 and $627 \mathrm{~km}^{2}$ for OLI 30 (Table 2). In August, inundated surfaces are equal to $250 \mathrm{~km}^{2}$ and are 2.5 times more important than OLI $30\left(98 \mathrm{~km}^{2}\right)$, if we consider OLI 30 as truth.

Time series of surface water extent in the Mackenzie Delta were derived from the 8-day maps of surface water extent (Fig. 4). Surface extent water varies from 1500 to $14284 \mathrm{~km}^{2}$ between 2000 and 2015 along the hydrological cycle. Each year, water surface area extent is at its maximum in June in response to the spring ice break-up and snow melt that occurred in May (between day of year, DOY, 110 and 130 on average) in the Delta and decreases to reach a minimum in September, as previously observed by Goulding et al. (2009a, b). On average, during the study period, maximum surface water extent is $\sim 9600 \mathrm{~km}^{2}$. The largest water surface area extent was reached in June 2006 with an inundated area of $14284 \mathrm{~km}^{2}$, which represents $\sim 85 \%$ of the delta total surface (Fig. 4). Large surface water extents $\left(\sim 12500 \mathrm{~km}^{2}\right)$ were also detected in 2011 and 2013 in accordance with high discharge peaks reported for these years (http://wateroffice.ec.gc.ca/) and the historic inundation that occurred in Aklavik in 2006 (Beltaos and Carter, 2009).

\subsection{Altimetry-based water levels and their validation}

The Mackenzie Delta is densely covered with altimetry tracks from the ERS-2, ENVISAT and SARAL missions that were all on the same nominal orbit. A total of 22, 27 and 
Table 1. Validation of surface water extents $\left(\mathrm{km}^{2}\right)$ determined using OLI $30 \mathrm{~m}$, OLI $500 \mathrm{~m}$, and MODIS $500 \mathrm{~m}$ images with the results of Emmerton et al. (2007).

\begin{tabular}{lrr}
\hline & $\begin{array}{r}\text { MODIS: 4 July 2013 } \\
\text { OLI: 1 July 2013 }\end{array}$ & $\begin{array}{r}\text { MODIS: 5 August 2013 } \\
\text { OLI: 2 August 2013 }\end{array}$ \\
\hline MODIS 500 m & 3798 & 3298 \\
\hline OLI 500 m & 4499 & 3859 \\
\hline $\begin{array}{l}\text { Emmerton et al. (2007) } \\
\left.\text { (channels + wetlands, km }{ }^{2}\right)\end{array}$ & 3358 & 3358 \\
\hline $\begin{array}{l}\text { Difference between MODIS 500 } \\
\text { and Emmerton et al. (2007) }\end{array}$ & $440 \mathrm{~km}^{2}(13 \%)$ & $50 \mathrm{~km}^{2}(2 \%)$ \\
\hline $\begin{array}{l}\text { Difference between OLI 500 } \\
\text { and Emmerton et al. (2007) }\end{array}$ & $1141(34 \%)$ & 7156 \\
\hline $\begin{array}{l}\text { OLI 30 m } \\
\text { Emmerton et al. (2007) } \\
\left.\text { (channels + lakes + wetlands, } \mathrm{km}^{2}\right)\end{array}$ & 7685 & 6689 \\
\hline $\begin{array}{l}\text { Difference between OLI 30 } \\
\text { and Emmerton et al. (2007) }\end{array}$ & 6689 & $467 \mathrm{~km}^{2}(7 \%)$ \\
\hline
\end{tabular}

Table 2. Satellite validation of surface water extent using OLI 30, OLI 500 and MODIS $500 \mathrm{~m}$.

\begin{tabular}{lrrrrrr}
\hline & $\begin{array}{r}\text { Permanent } \\
\text { water } \\
\text { MODIS } \\
\left(\mathrm{km}^{2}\right)\end{array}$ & $\begin{array}{r}\text { Permanent } \\
\text { water } \\
\text { OLI 500 } \\
\left(\mathrm{km}^{2}\right)\end{array}$ & $\begin{array}{r}\text { Permanent } \\
\text { water } \\
\left(\mathrm{km}^{2}\right)\end{array}$ & $\begin{array}{r}\text { Inundated } \\
\text { surfaces } \\
\text { MODIS } \\
\left(\mathrm{km}^{2}\right)\end{array}$ & $\begin{array}{r}\text { Inundated } \\
\text { surfaces } \\
\text { OLI 500 } \\
\left(\mathrm{km}^{2}\right)\end{array}$ & $\begin{array}{r}\text { Inundated } \\
\text { surfaces } \\
\text { OLI 30 } \\
\left(\mathrm{km}^{2}\right)\end{array}$ \\
\hline $\begin{array}{l}\text { MODIS : 4 July 2013 } \\
\text { OLI : 1 July 2013 }\end{array}$ & 3167 & 3809 & 7058 & 577 & 690 & 627 \\
\hline $\begin{array}{l}\text { MODIS : 5 August 2013 } \\
\text { OLI : 2 August 2013 }\end{array}$ & 2885 & 3809 & 7058 & 250 & 50 & 98 \\
\hline
\end{tabular}

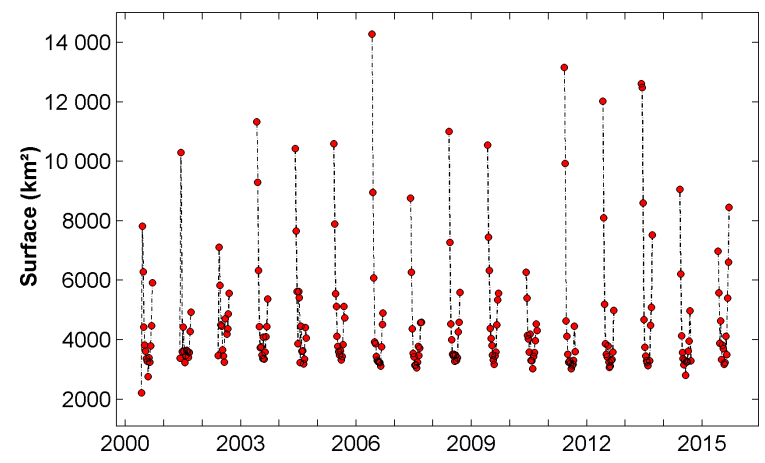

Figure 4. Time series of surface water extent from 2000 to 2015, between June and September, derived from the MODIS images.

24 altimetry virtual stations were built at the cross section of an altimetry track with a water body for these three missions respectively (see Fig. 5 for their locations). A water level temporal series is obtained for each virtual station.
The quality of altimetry-based water levels was evaluated using in situ gauge records. Only 6 virtual stations are located near in situ stations (with a distance lower than $20 \mathrm{~km}$ ) for ERS-2 data, with 10 for ENVISAT and 8 for SARAL data. Characteristics of these virtual stations are given in Table 3. For ERS-2 and SARAL comparisons, the correlation $r$ is low at the station $0114-$ c, i.e. -0.38 and 0.15 respectively (Table 3).

For ERS-2, quite high correlation coefficients are obtained for four virtual stations out of six, with $r \geq 0.69$ and RMS $\leq 1 \mathrm{~m}$ (Table 3). For the two other stations, no correlation is observed $(-0.38$ and 0.08 for ERS-2-0114c and ERS2-0200-d respectively with a RMS $\geq 1 \mathrm{~m}$ ) (Table 3).

For ENVISAT, 8 out of 10 stations have a correlation coefficient ranging between 0.66 and 0.93 (Table 3). Except for ENV-0572-a, which is located $22 \mathrm{~km}$ away from the nearest in situ station, higher correlations were found when the river is larger at the VS (Table 3). For example, ENV-0114$\mathrm{b}$ exhibits a negative correlation $(r=-0.27)$ where the cross 
Table 3. Statistic parameters obtained between altimetry-based water levels from altimetry multi-mission and in situ water levels.

\begin{tabular}{|c|c|c|c|c|c|c|c|c|c|c|}
\hline $\begin{array}{l}\text { Virtual } \\
\text { station } \\
(\mathrm{SV})\end{array}$ & In situ station & $\begin{array}{l}\text { Altimetry } \\
\text { mission }\end{array}$ & $\begin{array}{l}\text { Distance } \\
(\mathrm{km})\end{array}$ & $\begin{array}{l}\text { River } \\
\text { width } \\
\text { at VS } \\
\text { (m) }\end{array}$ & $N$ & $r$ & $\begin{array}{l}\text { RMS } \\
(\mathrm{m})\end{array}$ & $R^{2}$ & $\begin{array}{l}\text { Bias } \\
(\mathrm{m})\end{array}$ & $\begin{array}{l}\text { Bias } \\
\text { ICESat } \\
\text { (m) }\end{array}$ \\
\hline 0439-a & 10MC008 & $\begin{array}{l}\text { ERS-2 } \\
\text { ENVISAT } \\
\text { SARAL }\end{array}$ & 11.44 & 1950 & $\begin{array}{l}5 \\
24 \\
8\end{array}$ & $\begin{array}{l}0.76 \\
0.89 \\
0.96\end{array}$ & $\begin{array}{l}0.5 \\
0.5 \\
0.35\end{array}$ & $\begin{array}{l}0.58 \\
0.81 \\
0.93\end{array}$ & $\begin{array}{l}0.55 \\
0.15 \\
-0.95\end{array}$ & $\begin{array}{l}1.36 \\
0.65 \\
-0.15\end{array}$ \\
\hline 0983-c & $10 \mathrm{MC} 003$ & $\begin{array}{l}\text { ERS-2 } \\
\text { ENVISAT } \\
\text { SARAL }\end{array}$ & 3.1 & 360 & $\begin{array}{l}20 \\
26 \\
6\end{array}$ & $\begin{array}{l}0.69 \\
0.66 \\
0.9\end{array}$ & $\begin{array}{l}0.7 \\
0.89 \\
0.4\end{array}$ & $\begin{array}{l}0.47 \\
0.44 \\
0.8\end{array}$ & $\begin{array}{l}- \\
- \\
-\end{array}$ & $\begin{array}{l}- \\
- \\
-\end{array}$ \\
\hline 0114-c & $10 \mathrm{MC} 022$ & $\begin{array}{l}\text { ERS-2 } \\
\text { ENVISAT } \\
\text { SARAL }\end{array}$ & 1.9 & 430 & $\begin{array}{l}14 \\
23 \\
7\end{array}$ & $\begin{array}{l}-0.38 \\
0.8 \\
0.14\end{array}$ & $\begin{array}{l}2.82 \\
1.17 \\
0.73\end{array}$ & $\begin{array}{l}0.14 \\
0.64 \\
0.02\end{array}$ & $\begin{array}{l}- \\
- \\
-\end{array}$ & $\begin{array}{l}- \\
- \\
-\end{array}$ \\
\hline 0200-d & $10 \mathrm{MC} 023$ & $\begin{array}{l}\text { ERS-2 } \\
\text { ENVISAT } \\
\text { SARAL }\end{array}$ & 4.11 & 630 & $\begin{array}{l}17 \\
22 \\
6\end{array}$ & $\begin{array}{l}0.08 \\
0.87 \\
0.76\end{array}$ & $\begin{array}{l}4.3 \\
0.33 \\
0.3\end{array}$ & $\begin{array}{l}0 \\
0.75 \\
0.57\end{array}$ & $\begin{array}{l}- \\
- \\
-\end{array}$ & $\begin{array}{l}- \\
- \\
-\end{array}$ \\
\hline 0744-a & $10 \mathrm{MC} 010$ & $\begin{array}{l}\text { ERS-2 } \\
\text { ENVISAT } \\
\text { SARAL }\end{array}$ & 5.16 & 850 & $\begin{array}{l}5 \\
24 \\
2\end{array}$ & $\begin{array}{l}0.88 \\
0.93 \\
0.99\end{array}$ & $\begin{array}{l}0.1 \\
0.15 \\
0.15\end{array}$ & $\begin{array}{l}0.77 \\
0.87 \\
0.99\end{array}$ & $\begin{array}{l}- \\
- \\
-\end{array}$ & $\begin{array}{l}-1.28 \\
-1.17 \\
-2.19\end{array}$ \\
\hline 0439-d & 10LC015 & $\begin{array}{l}\text { ERS-2 } \\
\text { ENVISAT } \\
\text { SARAL }\end{array}$ & 7.2 & 380 & $\begin{array}{l}20 \\
28 \\
5\end{array}$ & $\begin{array}{l}0.92 \\
0.65 \\
0.95\end{array}$ & $\begin{array}{l}0.83 \\
1.75 \\
1.3\end{array}$ & $\begin{array}{l}0.86 \\
0.43 \\
0.9\end{array}$ & $\begin{array}{l}- \\
- \\
-\end{array}$ & $\begin{array}{l}- \\
- \\
-\end{array}$ \\
\hline 0525-a & $10 \mathrm{MC} 002$ & ENV & 16.31 & 500 & 29 & 0.77 & 1.45 & 0.6 & - & - \\
\hline 0028-a & 10LC014 & ENV & 16.05 & 1360 & 17 & 0.83 & 1.84 & 0.7 & - & 2.35 \\
\hline
\end{tabular}

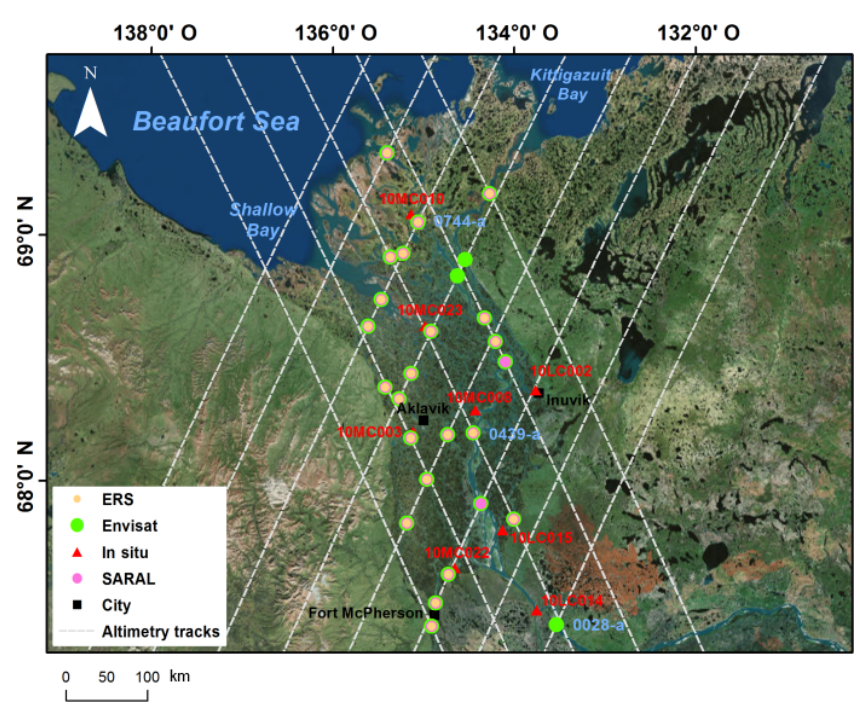

Figure 5. Locations of virtual stations (VSs) in the Mackenzie Delta for ERS-2 (yellow dots), Envisat (green dots) and SARAL (purple dots) altimetry missions. Altimetry tracks appear in grey. In situ stations are represented using red triangles. section was only $150 \mathrm{~m}$ wide (Table 3 ). This station is also located near the city of Inuvik. The presence of the town in the altimeter footprint could exert a strong impact on the radar echo and explain this low correlation.

For SARAL, five out of six virtual stations have a good correlation $r$ coefficient higher than 0.76 with a low RMS (Table 3) due to its narrower footprint with an increase in the along-track sampling.

Comparisons between water levels derived from altimetry and in situ are shown for two stations for ERS-2 (called ERS-2-0744-a and ERS-2-0439-a; Figs. 6a and 7a), three for ENVISAT (ENV-0744-a, ENV-0439-a and ENV-0028-a; in Figs. 6b, 7b and 8) and two for SARAL (SARAL-0744-a and SARAL-0439-a; Figs. 6c and 7c). Virtual station 0744$\mathrm{a}$ is located in the downstream part of the delta, 0439-a in the centre and 0028-a in the upstream part (Fig. 5). For each station, water levels obtained by altimetry and water levels obtained by in situ gauges are superposed (Figs. 6, 7 and 8). Then, water level anomalies, which are computed as the average water level minus the water level, have been calculated for altimetry and in situ data.

The virtual station 0744-a is located in the north of the Mackenzie Delta (Fig. 5). Water level time series have been processed between 1995 and 2015 and compared to in situ 

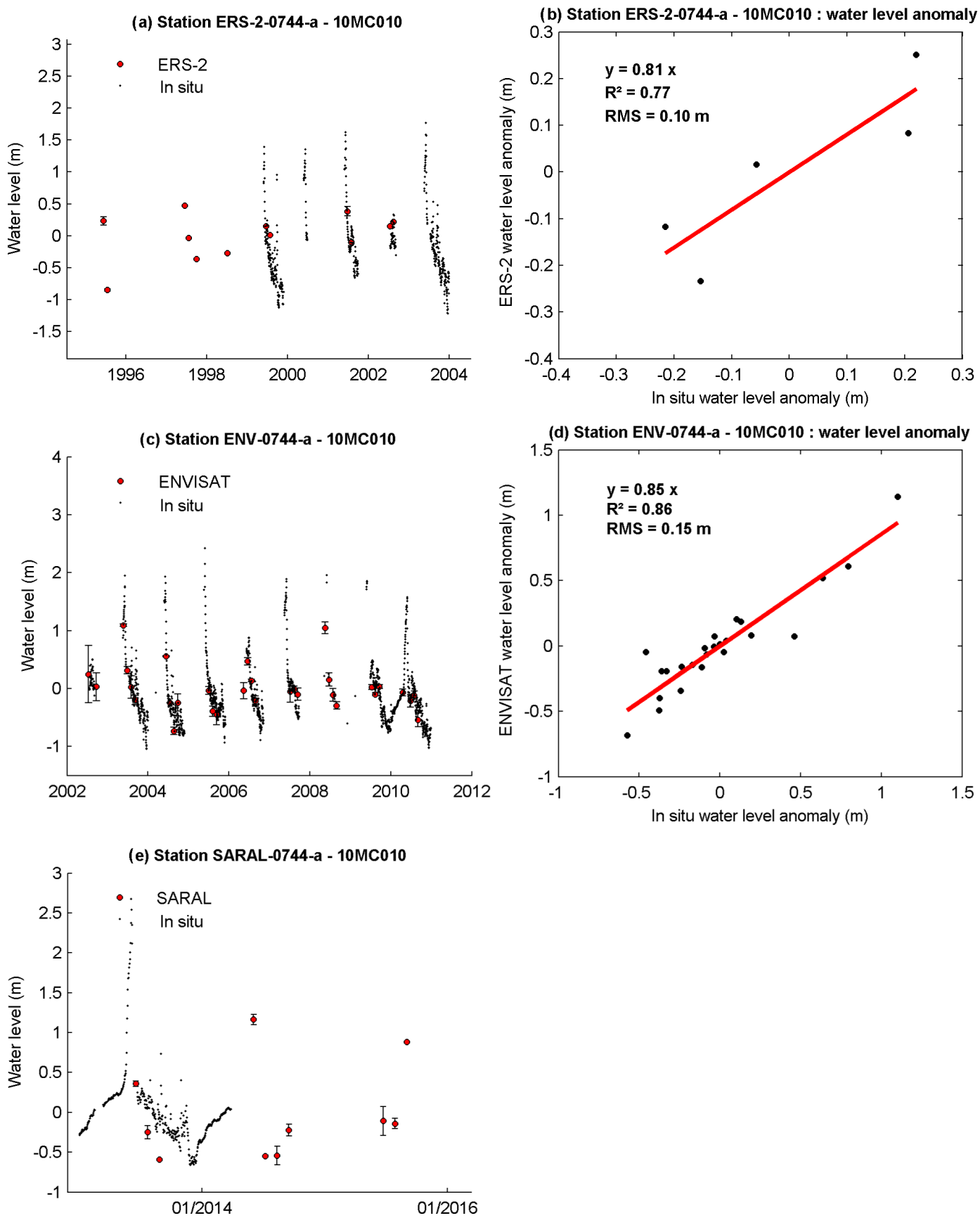

Figure 6. Altimetry-based water levels from 1995 to 2015 compared with in situ water levels for the station 0744-a, located in the downstream part in the Mackenzie Delta, using (a) the ERS-2 mission and (b) a water level anomaly with statistic parameters, (c) the ENVISAT mission and (d) a water level anomaly with statistic parameters, and (e) using SARAL mission.

data of the station $10 \mathrm{MC} 010$ for each mission ERS-2, ENVISAT and SARAL (Fig. 6). In situ data are not continuous since the river is frozen from October to April. With regard to altimetry, data have been acquired throughout the year, but during frozen periods water levels are unrealistic due to the presence of river ice. Thus, the processing is done only from the beginning of June to the end of September for multispectral imagery treatment. The correlation $r$ between altimetry water levels and in situ levels is 0.88 for ERS-2, 0.93 for ENVISAT and 0.99 for SARAL (Table 3). For the three missions, RMS is weak, lower than $0.15 \mathrm{~m}$ (Table 3). At this station, the variation of water level is about $2 \mathrm{~m}$ on average with an important water level in June that decreases to September (Fig. 7a, c and e).

The virtual station ERS-2-0439-a is in the centre of the Mackenzie Delta and water level time series have been 

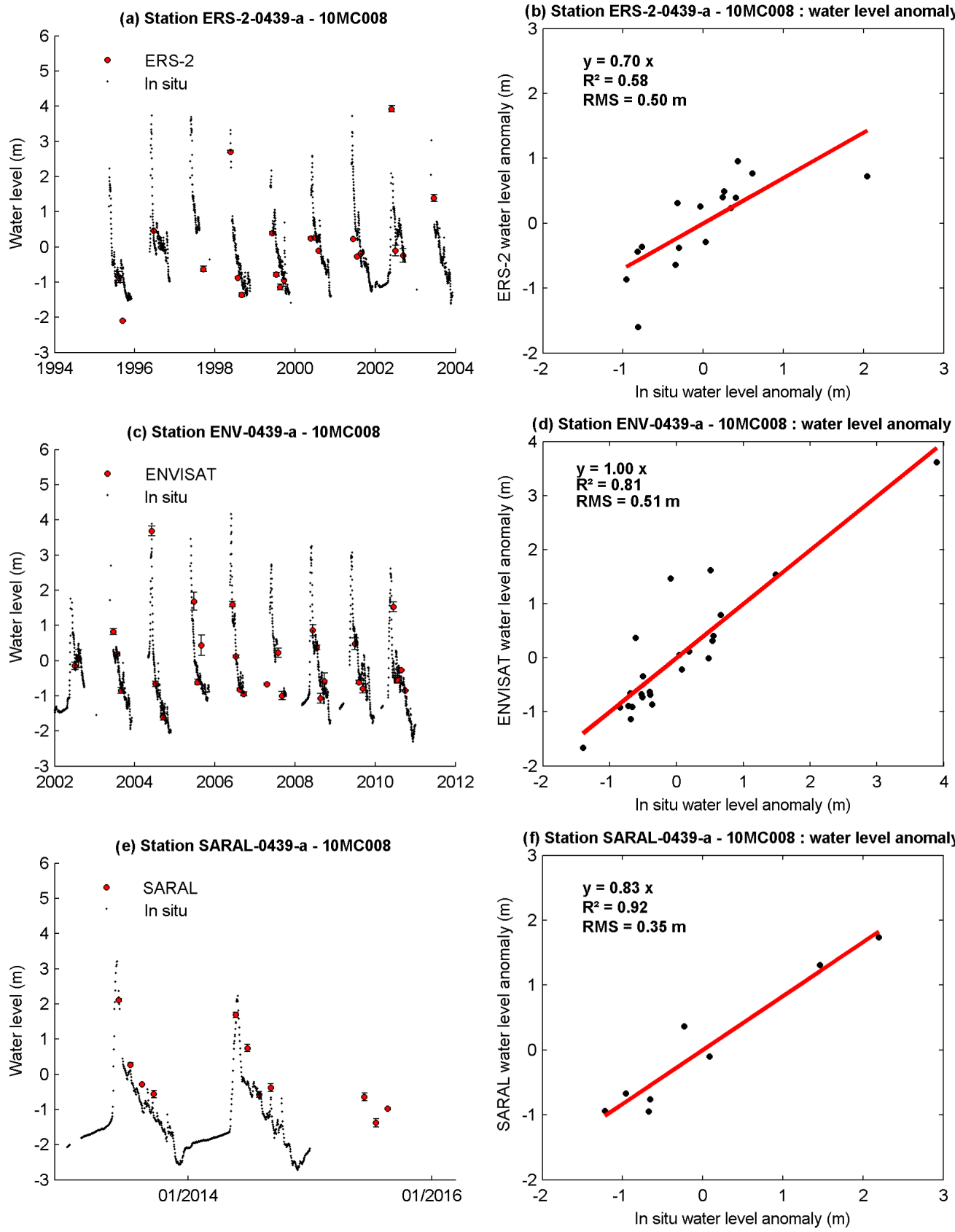

Figure 7. Altimetry-based water levels from 1995 to 2015 compared with in situ water levels for the station 0439-a located in the centre of the Mackenzie Delta using (a) the ERS-2 mission and (b) a water level anomaly with statistic parameters, (c) the ENVISAT mission and (d) a water level anomaly with statistic parameters, and (e) the SARAL mission and (f) a water level anomaly with statistic parameters.

recorded between 1995 and 2015 and compared to in situ data of the station 10MC008 for the three missions ERS2, ENVISAT and SARAL (Fig. 7). The correlation between altimetry water levels and water levels from in situ gauges is about 0.76 for ERS-2, 0.89 for ENVISAT and 0.96 for SARAL (Table 3). RMS is included between 0.35 and $0.5 \mathrm{~m}$ for the three missions. On average at this station, water levels variations are about $4 \mathrm{~m}$, with a maximal water level in
June that decreases to reach a minimal value in September (Fig. 7a, c and e).

Water level time series between 2002 and 2010 at the virtual station ENV-0028-a, located upstream of the Mackenzie Delta, have been compared to in situ data of the station 10LC014 (Fig. 8). A good correlation was found for this station too, with a coefficient correlation $r$ of 0.83 and a RMS of $1.84 \mathrm{~m}$ (Table 3 ). For this station, variations of water lev- 

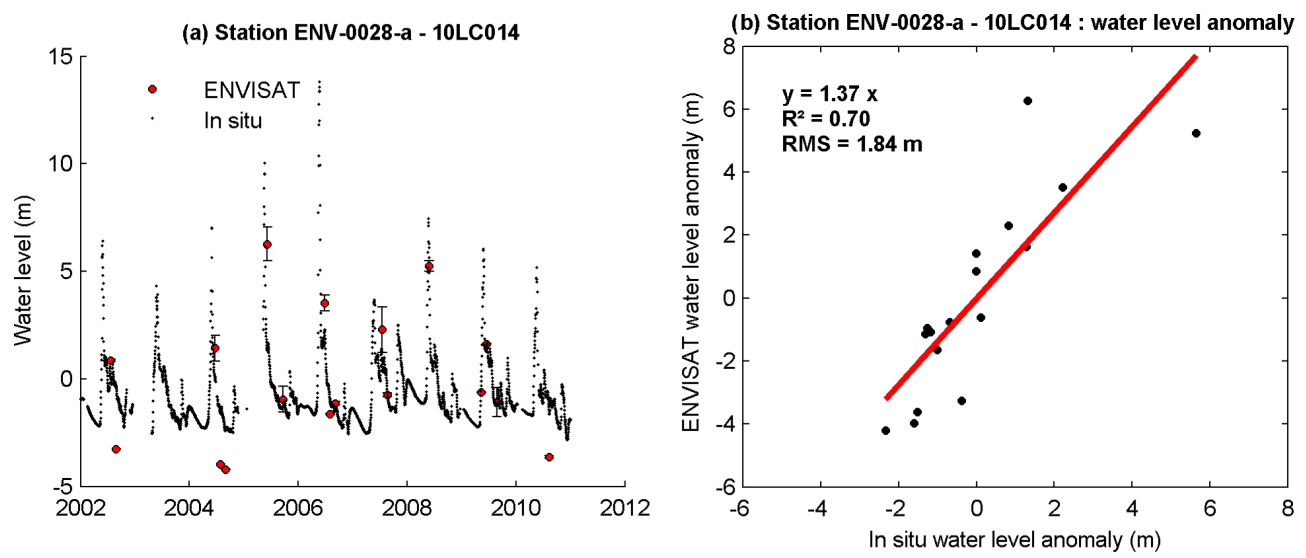

Figure 8. Altimetry-based water levels from 2002 to 2010 compared to in situ water levels for the station 0439-a located in the centre of the Mackenzie Delta (a) using ENVISAT mission and (b) water level anomaly with statistic parameters.

els are much higher, with $9 \mathrm{~m}$ on average, but reach $12 \mathrm{~m}$ during the 2006 extreme event (Fig. 8a). Water level time series were constructed only for ENVISAT mission since for the two others (ERS-2 and SARAL), altimetry water levels were not consistent, exhibiting values around $70 \mathrm{~m}$. Therefore, water levels determined by altimetry and water levels from in situ gauges have a difference, which is probably explained by the distance between virtual stations and in situ gauges $(16.31 \mathrm{~km})$ since the slope is about $-0.02 \mathrm{~m} \mathrm{~km}^{-1}$ in the Delta (Hill et al., 2001). Moreover, the seasonal cyclic thawing and freezing of the active layer causes cyclic settlement and heave at decimetre levels, estimated to $20 \mathrm{~cm}$ (Szostak-Chrzanowski, 2013).

\subsection{Time series of surface water storage anomalies in the Mackenzie Delta}

The minimum water level of each inundated pixel was determined over the observation period. Maps of 8-day surface water levels were created after subtracting the minimum water level to water level at time $t$, using MODIS-based flood extent and altimetry-derived water levels in the entire delta from June to September. Example of water level maps are presented for 2006 at 4 different dates (in June, July, August and September), characterized as an historic flood (Fig. 9).

Over the study period, water level maps show a realistic spatial pattern with a gradient of water level from south to north, consistent with flow direction in the delta. In Fig. 9a, in June 2006, for example, water levels are higher (about $5 \mathrm{~m}$ ) upstream than downstream (about $0.5 \mathrm{~m}$ ). The surface water storage reaches its maximal extent in June (Fig. 9a) and then decreases during the following months, reaching $1 \mathrm{~m}$ in September in the entire delta (Fig. 9b, c and d).

The time series of surface water volume variations was estimated from 2000 to 2010 and then from 2013 to 2015, between June and September, following a similar approach to that in Frappart et al., 2012 (Fig. 10). Surface water storage was estimated from 2000 to 2003 using ERS-2 data, from 2003 to 2010 using ENVISAT data and from 2013 to 2015 using SARAL. Between 2010 and 2013, surface water storage could not be estimated due to lack of RA data over the delta. The impact of the presence of a virtual station located in the upstream part of the delta and the inclusion of ERS-2 data on our satellite-based surface water volume estimation were assessed. For ERS-2 and SARAL data, no virtual station was created in the upstream part due to unreliable water levels in the upstream part of the delta. During the SARAL observation period, in situ water levels from 10LC014 station were used. One curve corresponds to surface water volume with virtual stations in the upstream part of the delta (20022015; red) and another one without virtual stations in the upstream part of the delta (2000-2015; green). Correlations between river discharges and surface water volumes with and without (2002-2015) upstream virtual stations are the same (0.66). In the presence of a virtual station in the upstream part of the Mackenzie, the water volume decreases by $\sim 0.3 \mathrm{~km}^{3}$ on average (Fig. 10). The correlation is lower (0.63) when ERS-2 data are included in the analysis (2000-2015). The integration of ERS-2 data has a lower accuracy and slightly decreases the correlation between water storage and flux.

In terms of temporal variability, a clear seasonal cycle is visible, with a yearly maximum of water surface area volume occurring in June (about $9.7 \mathrm{~km}^{3}$ on average), followed by a decrease until September (Fig. 10). The peak generally corresponds to the presence of the extensive flood covering the delta in June, and during summer the volume decreases to reach its minimal in September $\left(\sim 0.2 \mathrm{~km}^{3}\right)$. The largest surface water volume occurred in 2006 with a volume of $14.4 \mathrm{~km}^{3}$ (Fig. 10), known as an historic flood (Beltaos and Carter, 2009). These results showed that the satellitebased surface water volume estimation is consistent with the Mackenzie River discharge, which is the main driver of the delta flooding. 

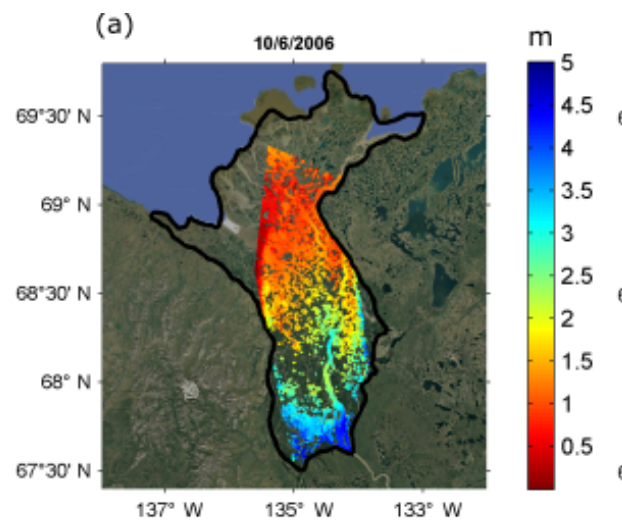

(b)
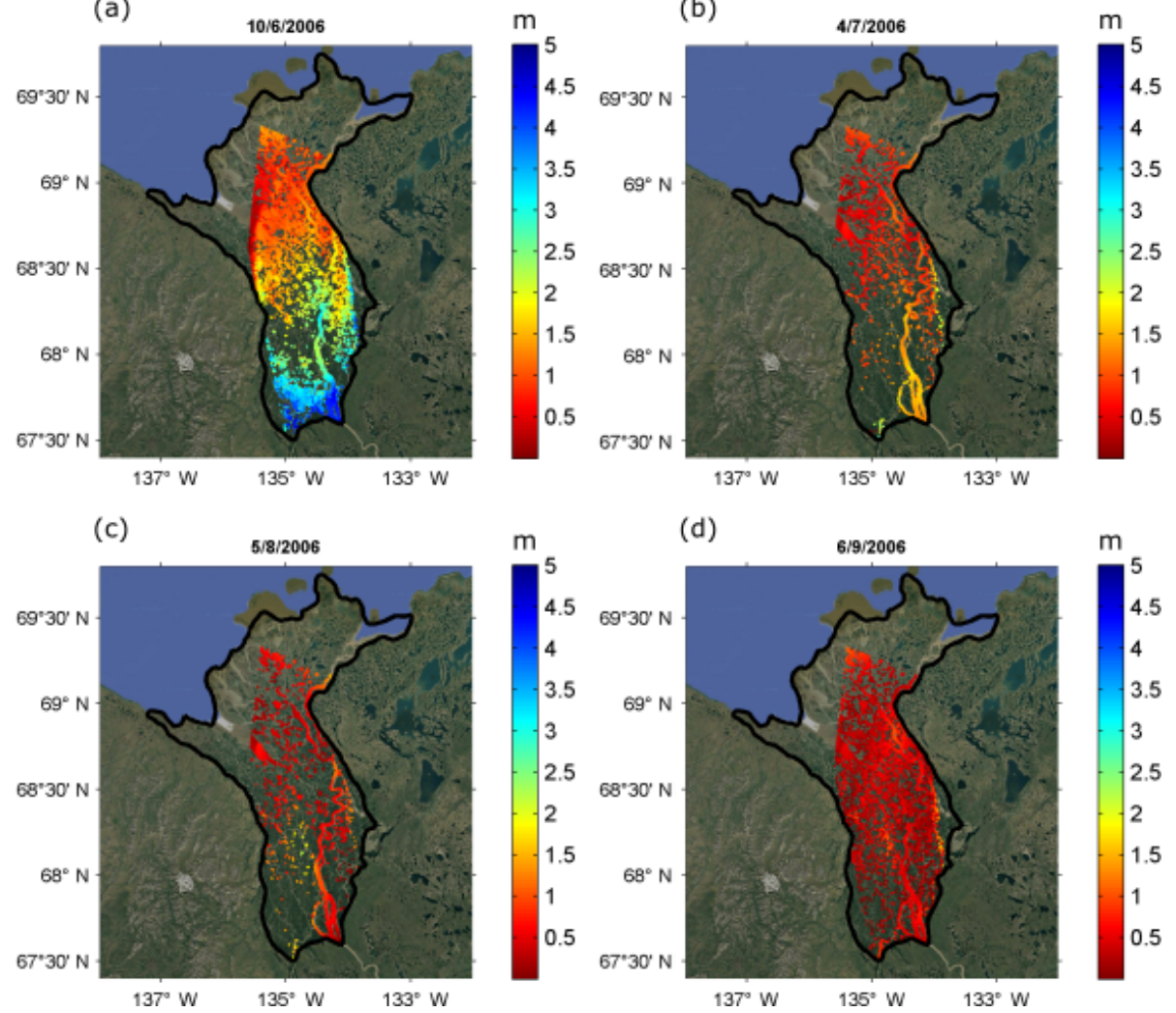

(d)
$6 / 9 / 2006$

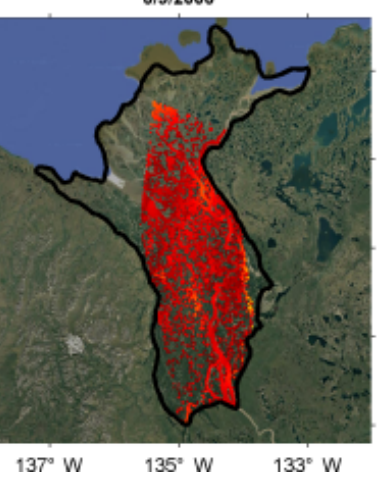

m

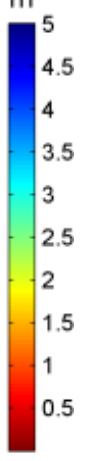

Figure 9. Water level maps in the Mackenzie Delta in 2006 (historic flood) obtained by combining inundated surfaces determined using MODIS images with altimetry-derived water levels (a) in June, (b) in July, (c) in August and (d) in September.

\section{Discussion}

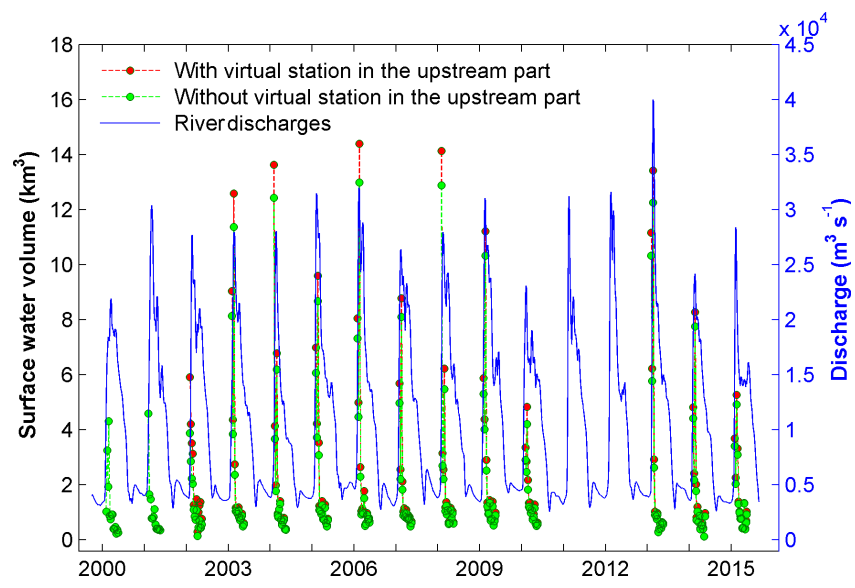

Figure 10. Surface water volume from 2000 to 2015, determined by combining inundated surfaces from MODIS with altimetry data; 167 red points correspond to surface water volume obtained with a virtual station located in the upstream part of the Delta, green points to surface water volume without a virtual station located in the upstream part of the Delta. The Mackenzie River Delta discharges at 10LC014 gauge station appear in blue.

\subsection{Spatio-temporal dynamics of surface water extent}

Maps of surface water extent duration for annual average from 2000 to 2015 exhibit important spatio-temporal variations along the Mackenzie Delta (Fig. 3a). Areas with open water present during the whole study period are located along the Mackenzie River and its tributaries. On the contrary, areas covered with open water for a duration lower than 30 days in the study period of 120 days are mostly located in the western upstream and eastern downstream parts of the delta but also in some locations in the western downstream part and along the Mackenzie mainstream (Fig. 3a). They correspond to regions only inundated in June during the floods caused by spring ice break-up and snow melt occurring in May (see Fig. 9 for the temporality of the flood extent). The central part of the Mackenzie is inundated between 40 and 70 days per year (Fig. 3a). As can be seen in Fig. 9, this area is not continuously inundated except for during two flood events in June in response to snowmelt and in August and September in response to an increase in river discharges of the Mackenzie River. This secondary peak ranges from 3000 to $5000 \mathrm{~km}^{2}$ in comparison with the earlier one that ranges from 4000 to $10000 \mathrm{~km}^{2}$ (Fig. 4). Maps of difference between the duration 
(a)

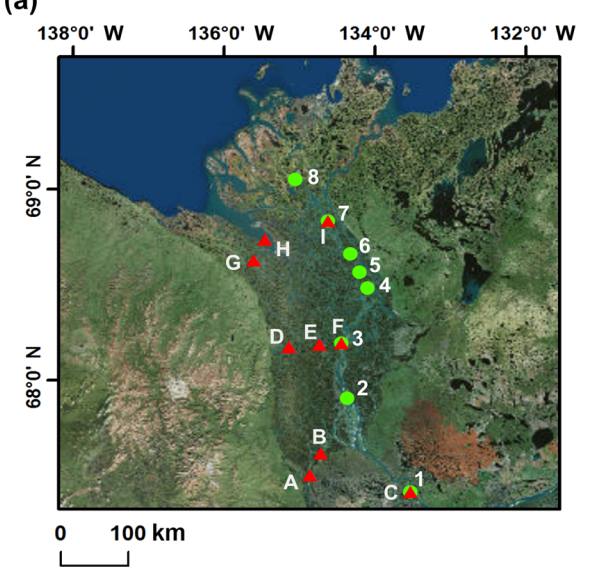

(c)

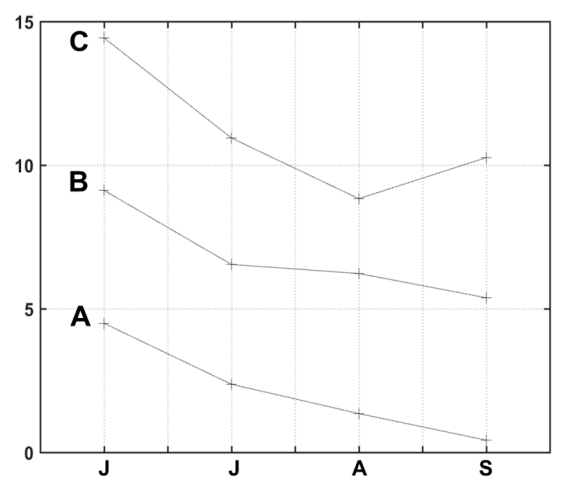

(b)

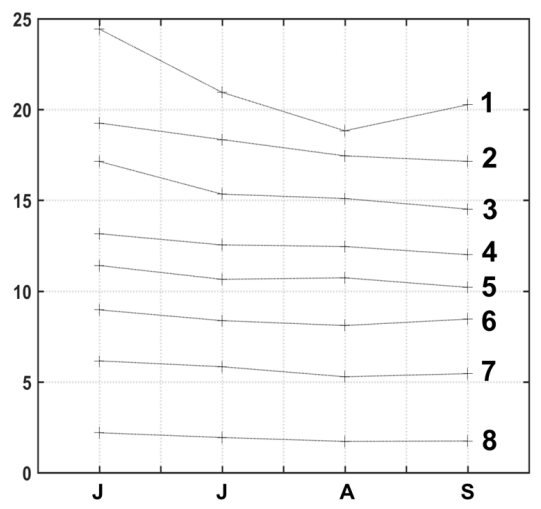

(d)

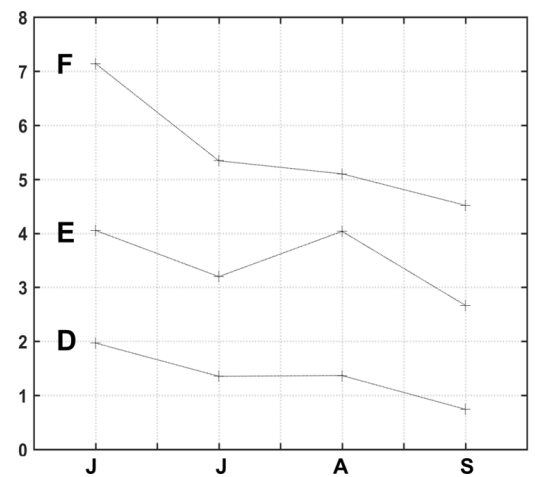

(e)

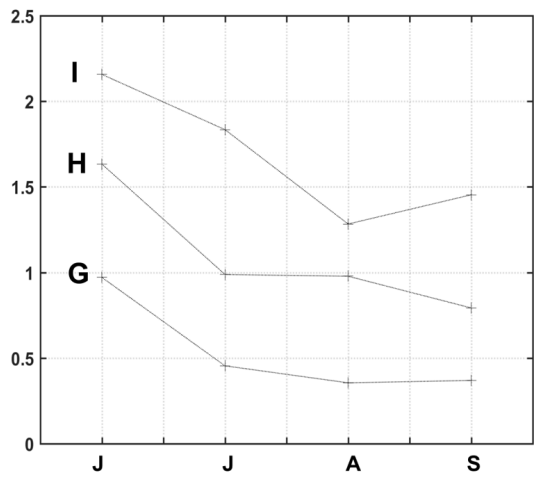

Figure 11. Temporal and spatial variations of surface water levels (in metres) in the Mackenzie Delta. (a) Location of virtual stations used to analyse spatial variations; green dots are corresponding to latitudinal variations along the Mackenzie River (from number 1 to 8 ) and red triangles are corresponding to longitudinal variations at three different latitudes (letters from A to I). (b) Surface water level time series along the Mackenzie River at different latitudes. Panels (c-e) show surface water levels time series at three different latitudes with three virtual stations at each latitude to analyse longitudinal spatial variations.

of extreme surface water surface area and the average water surface area duration from 2000 to 2015 were estimated for the large historic flood that occurred in 2006 (Fig. 3e) and for the minimal flood that occurred in 2010 (Fig. 3f). The whole Mackenzie Delta was practically covered in water in 2006, whereas large areas, especially in the downstream part of the delta, were not inundated in 2010 (Fig. 3f).

\subsection{Spatio-temporal dynamics of surface water levels in the Mackenzie delta}

For all stations and RA missions, a strong seasonal cycle can be seen, with a maximum water level reached in June after the spring ice break-up and snow melt that decreases to reach a minimal value in September, in good accordance with the hydrological cycle of the Mackenzie Delta. The delta is frozen from October to May, and during spring-early summer the freshwater meets an ice dam that was formed in winter, which provokes river discharge variations from $5000 \mathrm{~m}^{3}$ to $25000 \mathrm{~m}^{3}$ on average (http://wateroffice.ec.gc. ca/, Fig. 1b). Then, these important variations provoke water level increases and significant floods each year in the delta. However, water level variations as revealed from RA are not equal over the delta. In the upstream part, variations are $9 \mathrm{~m}$ on average, $4 \mathrm{~m}$ in the centre and $3 \mathrm{~m}$ in the downstream part of the Mackenzie Delta.

Water level time series from data acquired by the ENVISAT mission between June and September, averaged over 2002-2010, are presented in Fig. 11. Each time series has been shifted manually and errors are not shown here for clarity purposes. Virtual stations used to discuss the spatiotemporal variations were chosen along the Mackenzie River from upstream to downstream and at similar latitudes on the Mackenzie River and its tributaries. They are represented using green dots for variations along the Mackenzie River and red triangles for latitudinal variations (Fig. 11a). Time series from Fig. 11b are located along the Mackenzie River, number 1 corresponding to the upstream part and number 8 to the downstream part. Logically, a stronger seasonal cycle is observed upstream than downstream. If the primary peak of 
flooding that occurs in June clearly appears for all the stations, the secondary peak of August-September is not well marked for all the stations. This could be due to either local differences in the hydrodynamics of the river or due to the low temporal frequency of acquisition of the altimeters that is not sufficient to fully capture all specificities of the hydrological cycle (see Biancamaria et al., 2017 for instance). Latitudinal differences can also be noticed (Fig. 11c). Larger annual amplitudes of water levels can be observed in the Mackenzie River than over its tributaries. The second flood event occurs earlier in the central part (August) than in the western and eastern parts (September).

\subsection{Spatio-temporal dynamics of surface water storage}

The spatio-temporal dynamics of surface water storage is presented in Fig. 9 for 2006. A strong upstream-downstream gradient of water levels can be observed in June with water levels ranging 0 to $5 \mathrm{~m}$ from north to south (Fig. 9a). It strongly decreases in July ( 0 to $1.5 \mathrm{~m}$ in Fig. $9 \mathrm{~b}$ ) and does not appear in August (Fig. 9c) and September (Fig. 9d). For these two later months, differences in water levels are more homogeneous of the whole delta (except in a region located around $135^{\circ} \mathrm{W}$ and between $68^{\circ} \mathrm{N}$ and $68^{\circ} 30^{\prime} \mathrm{N}$ in August). Our results were compared to the ones estimated by Emmerton et al. (2007) under the assumption of a storage change as a rectangular water layer added to the average low-water volume for a stage variation from $1.231 \mathrm{~m}$ above sea level during a low-water period and $5.636 \mathrm{~m}$ above sea level during peak flooding. Using this approach, Emmerton et al. (2007) found an increase in water volume of $14.14 \mathrm{~km}^{3}$ over the floodplains and $7.68 \mathrm{~km}^{3}$ over the channels. With our method, maximal water volume is around $9.6 \mathrm{~km}^{3}$ on average and can reach $14 \mathrm{~km}^{3}$. As can be seen in Fig. 11, water levels present a strong decreasing gradient of amplitude over the delta towards the mouth and are, on average, lower than $5.636 \mathrm{~m}$ from Emmerton et al. (2007). The difference of approaches is likely to account for such discrepancy. The comparison between storage and flux (discharge) exhibits quite a good correlation ( $R=0.66$ with no time-lag) between these two quantities. Several studies demonstrated that there are no linear relationships among surface water extent, surface water volume and river discharge due to the presence of floodplains non-connected to the river (e.g. Frappart et al., 2005; Heimhuber et al., 2017). Due to the small area of the nonconnected lakes present in the Mackenzie delta, they are detected in our approach based on the use of MODIS images at $500 \mathrm{~m}$ of spatial resolution, as mixture areas (except during the June flood event where almost all the delta is inundated and all the flooded areas are connected to the river). Only the floodplains connected to river are considered in this study.

\section{Conclusion}

This study provides surface water estimates (permanent water of rivers, lakes and inundated surfaces connected to the rivers) dynamics both in extent and storage in the Mackenzie Delta from 2000 to 2015 using MODIS images at $500 \mathrm{~m}$ of spatial resolution and altimetry-based water levels. Surface water exhibits a maximal extent in the beginning of June and decreases to reach a minimal value in September. In June, the extent of water surface area is on average about $9600 \mathrm{~km}^{2}$. The highest value was observed in $2006\left(\sim 14284 \mathrm{~km}^{2}\right)$, during the historic flood described by Beltaos and Carter (2009). Despite the lower resolution of MODIS images in comparison with Landsat-8 images, surface water extent estimates are quite similar when using both sensors over the river channels and the floodplains, with an underestimation of $20 \%$ found for MODIS. But the numerous small lakes present in the Mackenzie Delta are not detected using MODIS. Nevertheless, the MODIS-based inundation product provides important information on flooding patterns along the hydrological cycle (flood events of June and August-September).

Virtual stations, or river-lake cross sections, have been created across the Mackenzie Delta for the three radar altimetry missions (ERS-2, 1993-2003; ENVISAT, 2002-2010; SARAL, since 2013). Due to the lack of valid data acquired in interferometry SAR mode by Cryosat-2, no information on surface water levels is available in 2011 and 2012. The water levels determined by altimetry at those stations have been validated with in situ river levels, with good correlation coefficients $(>0.8)$ for the three missions. The dense network of altimetry virtual stations composed of 22 stations for ERS2, 27 for ENVISAT and 24 for SARAL allowed the analysis of the spatio-temporal variations of water levels across the delta.

The combination between land water extent determined by MODIS imagery and the water levels derived from altimetry permitted estimation of surface water storage variations in the Mackenzie Delta at 8-day temporal resolution. Maps of surface water levels showed a clear upstream-downstream gradient in June that decreases with time. Temporal variations in surface water volume calculated from 2000 to 2010 and from 2012 to 2015 showed a maximal volume in June (on average $9.6 \mathrm{~km}^{3}$ ) and a minimal volume in September (about $0.1 \mathrm{~km}^{3}$ ). A relatively strong correlation was found between surface water volume and the Mackenzie River discharges $(R=0.66)$.

These products provide a unique long-term dataset that allows continuous monitoring of the changes affecting the surface water reservoir before the launch of the NASA-CNES Surface Water and Ocean Topography (SWOT) mission in 2021. This approach can be applied to any other deltaic and estuarine environments as MODIS and altimetry data are available globally. The major limitations are (i) the presence of clouds and dense vegetation cover that prevent the use of 
MODIS images, (ii) the relatively coarse spatial resolution of MODIS images, and (iii) the coarse coverage of altimetry tracks. They can be overcome (i) using SAR images for flood extent monitoring as in Frappart et al. (2005), (ii) using images with a higher spatial resolution, and (iii) combing information on the different altimetry missions orbiting simultaneously. The recent launches of Sentinel-1, Sentinel-2 and Sentinel-3 offer new opportunities for flood extent monitoring at higher spatial (from 10 to $300 \mathrm{~m}$ ) and temporal (a few days) resolutions. Associated with aquatic colour radiometry (Mouw et al., 2015), the approach developed here should provide useful information for the study of fluvial particle transport along the river-to-coastal ocean continuum and its potential impacts on ecosystems.

Data availability. Surface water extent, level and storage were estimated in the Mackenzie Delta, Canadian Northern Territories, using multi-sensor satellite observations. Surface water area extents were estimated from 2000 to 2015 using MODIS Terra reflectances (8day mosaic) at $500 \mathrm{~m}$ of spatial resolutions based on the Sakamoto et al. (2007) approach. Water levels were estimated using radar altimetry data from ERS-2 (1995-2003), ENVISAT (2003-2010) and SARAL (2013-2016). In total, 22, 27 and 24 virtual stations were built under the ground-tracks of these missions on their nominal orbit using the Multi-mission Altimetry Processing Software (MAPS) (Frappart et al., 2015b). Monthly surface water storage changes were obtained combining the two former datasets following the approach proposed in Frappart et al. (2006, 2012) on the common period of availability of the datasets. These datasets will be soon available on Hydroweb (http://hydroweb.theia-land.fr/). If you would like to access them before they are published here, you can contact Cassandra Normandin (cassandra.normandin@u-bordeaux.fr) and Frédéric Frappart (frederic.frappart@ legos.obs-mip.fr).

Supplement. The supplement related to this article is available online at: https://doi.org/10.5194/hess-22-1543-2018-supplement.

Competing interests. The authors declare that they have no conflict of interest.

Acknowledgements. This study was supported by an internship grant from LabEX Côte (Université de Bordeaux) and a $\mathrm{PhD}$ grant from Ministère de l'Enseignement Supérieur et de la Recherche and also by the CNES TOSCA CTOH grant. The authors also thank David Doxaran for fruitful discussion.

Edited by: Florian Pappenberger

Reviewed by: two anonymous referees

\section{References}

Alsdorf, D. E., Rodríguez, E., and Lettenmaier, D. P.: Measuring surface water from space, Rev. Geophys., 45, RG2002, https://doi.org/10.1029/2006RG000197, 2007.

Baup, F., Frappart, F., and Maubant, J.: Combining highresolution satellite images and altimetry to estimate the volume of small lakes, Hydrol. Earth Syst. Sci., 18, 2007-2020, https://doi.org/10.5194/hess-18-2007-2014, 2014.

Beltaos, S. and Carter, T.: Field studies of ice breakup and jamming in the Mackenzie Delta, St John's, Newfoundland and Labrador, CGU HS Committee on River Ice Processes and the Environment 15th Workshop on River Ice St. John's, Newfoundland and Labrador, 15-17 June 2009.

Beltaos, S., Carter, T., and Rowsell, R.: Measurements and analysis of ice breakup and jamming characteristics in the Mackenzie Delta, Canada, Cold Reg. Sci. Technol., 82, 110-123, https://doi.org/10.1016/j.coldregions.2012.05.013, 2012.

Biancamaria, S., Frappart, F., Leleu, A.-S., Marieu, V., Blumstein, D., Desjonquères, J.-D., Boy, F., Sottolichio, A., and ValleLevinson, A.: Satellite radar altimetry elevations performance over a $200 \mathrm{~m}$ wide river: Evaluation over the Garonne River, Adv. Space Res., 59, 128-146, 2017.

Birkett, C. M.: The contribution of TOPEX/POSEIDON to the global monitoring of climatically sensitive lakes, J. Geophys. Res., 100, 179-204, 1995.

Cazenave, A., Bonnefond, P., Dominh, K., and Schaeffer, P.: Caspian Sea level from Topex-Poseidon altimetry: Level now falling, Geophys. Res. Lett., 24, 881-884, https://doi.org/10.1029/97GL00809, 1997.

Crétaux, J.-F., Jelinski, W., Calmant, S., Kouraev, A., Vuglinski, V., Bergé-Nguyen, M., Gennero, M.-C., Nino, F., Abarca Del Rio, R., Cazenave, A., and Maisongrande, P.: SOLS: A lake database to monitor in the Near Real Time water level and storage variations from remote sensing data, Adv. Space Res., 47, 1497-1507, https://doi.org/10.1016/j.asr.2011.01.004, 2011a.

Crétaux, J.-F., Bergé-Nguyen, M., Leblanc, M., and Abarca Del Rio, R.: Flood Mapping Inferred From Remote Sensing Data, Fifteenth International Water Technology Conference, IWTC-15 2011, Alexandria, Egypt, 2011b.

Crétaux, J. F., Nielsen, K., Frappart, F., Papa, F., Calmant, S., and Benveniste, J.: Hydrological applications of satellite altimetry: rivers, lakes, man-made reservoirs, inundated areas, in: Satellite Altimetry Over Oceans and Land Surfaces, edited by: Stammer, D. and Cazenave, A., 644 pp., CRC press, 2017.

Emmerton, C. A., Lesack, L. F. W., and Marsh, P.: Lake Abundance, potential water storage, and habitat distribution in the Mackenzie River Delta, western Canadian Arctic, Water Resour. Res., 43, W05419, https://doi.org/10.1029/2006WR005139, 2007.

Emmerton, C. A., Lesack, L. F. W., and Vincent, W. F.: Nutrient and organic matter patterns across the Mackenzie River, estuary and shelf during the seasonal recession of sea-ice, J. Mar. Syst., 74, 741-755, https://doi.org/10.1016/j.jmarsys.2007.10.001, 2008.

Frappart, F., Seyler, F., Martinez, J. M., Léon, J. G., and Cazenave, A.: Floodplain water storage in the Negro River basin estimated from microwave remote sensing of inundation area and water levels, Remote Sens. Environ., 99, 387-399, https://doi.org/10.1016/j.rse.2005.08.016, 2005.

Frappart, F., Calmant, S., Cauhope, M., Seyler, F., and Cazenave, A.: Preliminary results of ENVISAT RA-2-derived water levels 
validation over the Amazon basin, Remote Sens. Environ., 100, 252-264, https://doi.org/10.1016/j.rse.2005.10.027, 2006a.

Frappart, F., Minh, K. D., L'Hermitte, J., Cazenave, A., Ramillien, G., Le Toan, T., and Mognard-Campbell, N.: Water volume change in the lower Mekong from satellite altimetry and imagery data, Geophys. J. Int., 167, 570-584, https://doi.org/10.1111/j.1365-246X.2006.03184.x, 2006b.

Frappart, F., Papa, F., Güntner, A., Werth, S., Ramillien, G., Prigent, C., Rossow, W. B., and Bonnet, M.-P.: Interannual variations of the terrestrial water storage in the Lower Ob' Basin from a multisatellite approach, Hydrol. Earth Syst. Sci., 14, 2443-2453, https://doi.org/10.5194/hess-14-2443-2010, 2010.

Frappart, F., Papa, F., Santos da Silva, J., Ramillien, G., Prigent, C., Seyler, F., and Calmant, S.: Surface freshwater storage and dynamics in the Amazon basin during the 2005 exceptional drought, Environ. Res. Lett., 7, 044010, https://doi.org/10.1088/1748-9326/7/4/044010, 2012.

Frappart, F., Papa, F., Malbeteau, Y., León, J., Ramillien, G., Prigent, C., Seoane, L., Seyler, F., and Calmant, S.: Surface Freshwater Storage Variations in the Orinoco Floodplains Using Multi-Satellite Observations, Remote Sens., 7, 89-110, https://doi.org/10.3390/rs70100089, 2015a.

Frappart, F., Papa, F., Marieu, V., Malbeteau, Y., Jordy, F., Calmant, S., Durand, F., and Bala, S.: Preliminary Assessment of SARAL/AltiKa Observations over the GangesBrahmaputra and Irrawaddy Rivers, Mar. Geod., 38, 568-580, https://doi.org/10.1080/01490419.2014.990591, 2015 b.

Frappart, F., Legrésy, B., Niño, F., Blarel, F., Fuller, N., Fleury, S., Birol, F., and Calmant, S.: An ERS-2 altimetry reprocessing compatible with ENVISAT for long-term land and ice sheets studies, Remote Sens. Environ., 184, 558-581, https://doi.org/10.1016/j.rse.2016.07.037, 2016.

$\mathrm{Fu}$, L.-L. and Cazenave, A. (Eds.): Satellite altimetry and earth sciences: a handbook of techniques and applications, Academic Press, San Diego, 2001.

Goulding, H. L., Prowse, T. D., and Bonsal, B.: Hydroclimatic controls on the occurrence of break-up and ice-jam flooding in the Mackenzie Delta, NWT, Canada, J. Hydrol., 379, 251-267, https://doi.org/10.1016/j.jhydrol.2009.10.006, 2009a.

Goulding, H. L., Prowse, T. D., and Beltaos, S.: Spatial and temporal patterns of break-up and ice-jam flooding in the Mackenzie Delta, NWT, Hydrol. Process., 23, 2654-2670, https://doi.org/10.1002/hyp.7251, 2009b.

Heimhuber, V., Tulbure, M. G., and Broich, M.: Modeling multidecadal surface water inundation dynamics and key drivers on large river basin scale using multiple time series of Earthobservation and river flow data, Water Resour. Res., 53, 12511269, https://doi.org/10.1002/2016WR019858, 2017.

Hill, P. R., Lewis, C. P., Desmarais, S., Kauppaymuthoo, V., and Rais, H.: The Mackenzie Delta: sedimentary processes and facies of a high-latitude, fine-grained delta, Sedimentology, 48, 10471078, https://doi.org/10.1046/j.1365-3091.2001.00408.x, 2001.

Holmes, R. M., McClelland, J. W., Peterson, B. J., Tank, S. E., Bulygina, E., Eglinton, T. I., Gordeev, V. V., Gurtovaya, T. Y., Raymond, P. A., Repeta, D. J., Staples, R., Striegl, R. G., Zhulidov, A. V., and Zimov, S. A.: Seasonal and Annual Fluxes of Nutrients and Organic Matter from Large Rivers to the Arctic Ocean and Surrounding Seas, Estuaries Coasts, 35, 369-382, https://doi.org/10.1007/s12237-011-9386-6, 2012.
Huete, A. R., Liu, H. Q., Batchily, K., and van Leeuwen, W.: A comparison of vegetation indices over a global set of TM images for EOS-MODIS, Remote Sens. Environ., 59, 440-451, 1997.

Klein, I., Gessner, U., Dietz, A. J., and Kuenzer, C.: Global WaterPack - A $250 \mathrm{~m}$ resolution dataset revealing the daily dynamics of global inland water bodies, Remote Sens. Environ., 198, 345362, https://doi.org/10.1016/j.rse.2017.06.045, 2017.

Lesack, L. F. W. and Marsh, P.: River-to-lake connectivities, water renewal, and aquatic habitat diversity in the Mackenzie River Delta, Water Resour. Res., 46, W12504, https://doi.org/10.1029/2010WR009607, 2010.

Macdonald, R. W. and Yu, Y.: The Mackenzie Estuary of the Arctic Ocean, in Estuaries, vol. 5H, edited by: P. J. Wangersky, 91-120, Springer-Verlag, Berlin/Heidelberg, available at: http: //link.springer.com/10.1007/698_5_027 (last access: 14 December 2016), 2006.

Mouw, C. B., Greb, S., Aurin, D., DiGiacomo, P. M., Lee, Z., Twardowski, M., Binding, C., Hu, C., Ma, R., Moore, T., Moses, W., and Craig, S. E.: Aquatic color radiometry remote sensing of coastal and inland waters: Challenges and recommendations for future satellite missions, Remote Sens. Environ., 160, 15-30, https://doi.org/10.1016/j.rse.2015.02.001, 2015.

Muhammad, P., Duguay, C., and Kang, K.-K.: Monitoring ice break-up on the Mackenzie River using MODIS data, The Cryosphere, 10, 569-584, https://doi.org/10.5194/tc-10-5692016, 2016.

Ogilvie, A., Belaud, G., Delenne, C., Bailly, J.-S., Bader, J.-C., Oleksiak, A., Ferry, L., and Martin, D.: Decadal monitoring of the Niger Inner Delta flood dynamics using MODIS optical data, J. Hydrol., 523, 368-383, https://doi.org/10.1016/j.jhydrol.2015.01.036, 2015.

Papa, F., Prigent, C., Aires, F., Jimenez, C., Rossow, W. B., and Matthews E.: Interannual variability of surface water extent at the global scale, 1993-2004, J. Geophys. Res., 115, D12111, https://doi.org/10.1029/2009JD012674, 2010.

Pekel, J., Cottam, A., Gorelick, N., and Belward, A. S.: High resolution mapping of global surface water and its long-term changes, Nature, 540, 418-422, https://doi.org/10.1038/nature20584, 2016

Peterson, B. J., Holmes, R. M., McClelland, J. W., Vörösmarty, C. J., Lammers, R. B., Shiklomanov, A. I., Shiklomanov, I. A., and Rahmstorf, S.: Increasing River Discharge to the Arctic Ocean, Science, 298, 2171-2173, https://doi.org/10.1126/science.1077445, 2002.

Rees, W. G.: Physical principles of remote sensing, Cambridge University press, 460 pp., 2013.

Sakamoto, T., Van Nguyen, N., Kotera, A., Ohno, H., Ishitsuka, N., and Yokozawa, M.: Detecting temporal changes in the extent of annual flooding within the Cambodia and the Vietnamese Mekong Delta from MODIS timeseries imagery, Remote Sens. Environ., 109, 295-313, https://doi.org/10.1016/j.rse.2007.01.011, 2007.

Santos da Silva, J., Calmant, S., Seyler, F., Rotunno Filho, O. C., Cochonneau, G., and Mansur, W. J.: Water levels in the Amazon basin derived from the ERS 2 and ENVISAT radar altimetry missions, Remote Sens. Environ., 114, 2160-2181, https://doi.org/10.1016/j.rse.2010.04.020, 2010.

Smith, L. C.: Satellite remote sensing of river inundation area, stage, and discharge: a review, Hydrol. Pro- 
cess., 11, 1427-1439, https://doi.org/10.1002/(SICI)10991085(199708)11:10<1427::AID-HYP473>3.0.CO;2-S, 1997.

Squires, M. M., Lesack, L. F. W., Hecky, R. E., Guildford, S. J., Ramlal, P., and Higgins, S. N.: Primary Production and Carbon Dioxide Metabolic Balance of a Lake-Rich Arctic River Floodplain: Partitioning of Phytoplankton, Epipelon, Macrophyte, and Epiphyton Production Among Lakes on the Mackenzie Delta, Ecosystems, 12, 853-872, https://doi.org/10.1007/s10021-0099263-3, 2009.

Stocker, T. F. and Raible, C. C.: Water cycles shifts gear, Nature, 434, 830-831, 2005.

Szostak-Chrzanowski, A.: Study of Natural and Maninduced Ground Deformation in MacKenzie Delta Region, Acta Geodyn. Geomater., 11, 117-123, https://doi.org/10.13168/AGG.2013.0060, 2013.

Tulbure, M. G., Broich, M., Stehman, S. V., and Kommareddy, A.: Surface water extent dynamics from the three decades of seasonally continuous Landsat time series at subcontinental scale in a semi-arid region, Remote Sens. Environ., 178, 142-157, https://doi.org/10.1016/j.rse.2016.02.034, 2016.

Ulaby, F. T., Moore, R. K., and Fung, A. K.: Microwave remote sensing: Active and passive, Volume 1 - Microwave remote sensing fundamentals and radiometry, available at: https: //ntrs.nasa.gov/search.jsp?R=19820039342 (last access: 15 December 2016), 1981.
Verpoorter, C., Kutser, T., Seekell, D. A., and Tranvik, L. J.: A global inventory of lakes based on high-resolution satellite imagery, Geophys. Res. Lett., 41, 6396-6402, https://doi.org/10.1002/2014GL060641, 2014.

Verron, J., Sengenes, P., Lambin, J., Noubel, J., Steunou, N., Guillot, A., Picot, N., Coutin-Faye, S., Sharma, R., Gairola, R. M., Murthy, D. V. A. R., Richman, J. G., Griffin, D., Pascual, A., Rémy, F., and Gupta, P. K.: The SARAL/AltiKa Altimetry Satellite Mission, Mar. Geod., 38, 2 21, https://doi.org/10.1080/01490419.2014.1000471, 2015.

Wang, M. and Shi, W. Estimation of ocean contribution at the MODIS near-infrared wavelengths along the east coast of the U.S.: Two case studies, Geophys. Res. Lett., 32, L13606, https://doi.org/10.1029/2005GL022917, 2005.

Xiao, X., Boles, S., Liu, J., Zhuang, D., Frolking, S., Li, C., Salas, W., and Moore, B.: Mapping paddy rice agriculture in southern China using multi-temporal MODIS images, Remote Sens. Environ., 95, 480-492, https://doi.org/10.1016/j.rse.2004.12.009, 2005

Zelli, C.: ENVISAT RA-2 Advances Radar Altimeter: instrument design and pre-launch performance assessment review, Acta Astronaut., 44, 323-333, 1999. 